

\section{Rethinking Music through Science and Technology Studies}

This volume seeks to offer a new approach to the study of music through the lens of recent works in science and technology studies (STS), which propose that facts are neither absolute truths, nor completely relative, but emerge from an intensely collective process of construction. Applied to the study of music, this approach enables us to reconcile the human, social, factual, and technological aspects of the musical world, and opens the prospect of new areas of inquiry in musicology and sound studies.

Rethinking Music through Science and Technology Studies draws together a wide range of both leading and emerging scholars to offer a critical survey of STS applications to music studies, considering topics ranging from classical music instrument-making to the ethos of DIY in punk music. The book's four sections focus on key areas of music study that are impacted by STS: organology, sound studies, music history, and epistemology. Raising crucial methodological and epistemological questions about the study of music, this book will be relevant to scholars studying the interactions between music, culture, and technology from many disciplinary perspectives.

Antoine Hennion is Professor at Mines ParisTech, and the former Director of the Centre for the Sociology of Innovation. He has written extensively on the sociology of music, media, and cultural industries.

Christophe Levaux is a lecturer and postdoctoral researcher at the University of Liège, Belgium. His research focuses on approaches to 20th-century American music and Actor-Network Theory. 


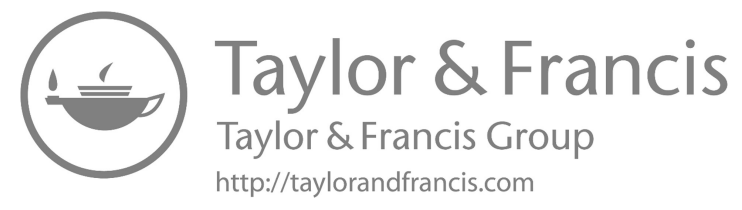




\section{Rethinking Music through Science and Technology Studies}

Edited by Antoine Hennion and Christophe Levaux 
First published 2021

by Routledge

2 Park Square, Milton Park, Abingdon, Oxon OX14 4RN

and by Routledge

52 Vanderbilt Avenue, New York, NY 10017

Routledge is an imprint of the Taylor \& Francis Group, an informa business

(C) 2021 selection and editorial matter, Antoine Hennion and Christophe

Levaux; individual chapters, the contributors

The right of Antoine Hennion and Christophe Levaux to be identified as the authors of the editorial material, and of the authors for their individual chapters, has been asserted in accordance with sections 77 and 78 of the Copyright, Designs and Patents Act 1988.

All rights reserved. No part of this book may be reprinted or reproduced or utilised in any form or by any electronic, mechanical, or other means, now known or hereafter invented, including photocopying and recording, or in any information storage or retrieval system, without permission in writing from the publishers.

Trademark notice: Product or corporate names may be trademarks or registered trademarks, and are used only for identification and explanation without intent to infringe.

British Library Cataloguing-in-Publication Data

A catalogue record for this book is available from the British Library

Library of Congress Cataloging-in-Publication Data

A catalog record has been requested for this book

ISBN: 978-0-367-20054-1 (hbk)

ISBN: 978-0-367-76772-3 (pbk)

ISBN: 978-0-429-26883-0 (ebk)

Typeset in Times New Roman

by Deanta Global Publishing Services, Chennai, India 


\section{Contents}

Acknowledgments

viii

List of contributors

Foreword: Sociology and the arts: A few remarks

by Howard S. Becker

Introduction

ANTOINE HENNION AND CHRISTOPHE LEVAUX

PART I

Histories

1 Rameau and harmony: Can theory make reason of music?

ANTOINE HENNION

2 Sounding standards: A history concert pitch, between musicology and STS

FANNY GRIBENSKI

3 Is DIY a punk invention?: Learning processes, recording devices, and social knowledge

FRANÇOIS RIBAC

4 Secure and insecure bases in the performance of Western classical music

DANIEL LEECH-WILKINSON

5 Deep structure: The generative subject in actor-network theory and musicology 
vi Contents

\section{PART II}

Instruments

6 Sonic imaginaries: How Hugh Davies and David Van

Koevering performed electronic music's future

JAMES MOONEY AND TREVOR PINCH

7 Following the instruments: The designers and users of the Fairlight CMI

PAUL HARKINS

8 The interface and instrumentality of Eurorack modular synthesis

ELIOT BATES

\section{PART III}

Technologies

9 Human sounds and the obscenity of information

DAVID TRIPPETT

10 STS confronts the Vocaloid: Assemblage thinking with

Hatsune Miku

NICK PRIOR

11 Similarity and difference in sound studies (and elsewhere)

\section{PART IV}

Practices

12 Smartphones, streaming platforms, and the infrastructuring of digital music practices

PAOLO MAGAUDDA

13 Tracing the music actor-network: Losing the meaning of musical experience? The limits of a routinization of science and technology studies applied to techniques and knowledges of music 256 FRANÇOIS DEBRUYNE 
14 Musicalized images: Composing, playing, remixing, and performing net art

JEAN-PAUL FOURMENTRAUX

Index 


\section{Acknowledgments}

Our deepest thanks go to Ben Alexander, Howard S. Becker, Anna K. Little, Benjamin Piekut, Christophe Pirenne, and Rose Vekony.

This work was supported by the Fonds de la Recherche Scientifique - FNRS under Grant No. 31288100. 


\section{Contributors}

Eliot Bates, The Graduate Center, City University of New York

Eliot Bates, an ethnomusicologist by training, has contributed new approaches to the study of music's instruments, materialities, technologies, infrastructures, and production workflows. From 2004 to 2016 he researched these within Istanbul's recording studios, luthieries and music industry; since 2013, his work has broadened geographically to consider European, North American and Australian audio technology gear cultures. Committed to social science and ethnographic methods, he also incorporates an experimental practice-led research design, whether that entails his ongoing studio-based audio engineering work, collaborative recordings featuring the ud, Eurorack performances for the New York Modular Society, and microtonal electronic music productions as the artist Makamqore.

François Debruyne, University of Lille

François Debruyne is a senior lecturer in the Department of Culture and Social Sciences at the University of Lille and a member of the research laboratory GERIICO. He has been coordinator of the Master degree Culture \& Communication since 2006. His research focuses on musical experience and public experience, as well as on their contemporary transformations. It may concern the music trade, listening practices, apparatus and situations in everyday life, the meaning of popular musical styles as public culture, ways of presence in public, ways of sharing or even of disqualifying these experiences. His ethnographic and ecological approach articulates anthropology of knowledge, sociology of mediation, urban sociology, and a great influence of ethnomethodology, pragmatist philosphy, and phenomenology. From these investigations on music experiencing and its resonance, his latest questioning concerns the links between this kind of experience and micropolitical situations, or avoidance of alienating situations.

Jean-Paul Fourmentraux, Aix-Marseille Université

Jean-Paul Fourmentraux, socio-anthropologist, is Professor of Philosophy and Sociology of Arts, Media and Digital humanities at the University of AixMarseille. Research Director (HDR Sorbonne) at the School of Advanced Studies in the Social Sciences (EHESS), member of the Norbert Elias Center 
(UMR-CNRS 8562) and initiator of the Art-Science-Society program at the Mediterranean Institute of Advanced Studies (IMéRA, RFIEA). He is also a member of the International Association of Art Critics (AICA). His interdisciplinary work focuses on political and anthropological issues in technologies and contemporary arts. He is the author of several books: Art et internet, Laboratory artists, L'oeuvre commune. Art and citizens matters, L'Euvre virale. Net art and culture Hacker, antiDATA, digital disobedience and edited the books L'Ere Post-media, Art et Science, Digital Identities, Digital Stories, Interactive Images.

\section{Fanny Gribenski, CNRS-IRCAM-Sorbonne Université}

Fanny Gribenski is a Research Scholar at the Centre National de la Recherche Scientifique and IRCAM in Paris. She studied musicology and history at the École Normale Supérieure of Lyon, the Paris Conservatory, and the École des hautes études en sciences sociales where she obtained her $\mathrm{PhD}$ in 2015. Her first book, L'Église comme lieu de concert. Pratiques musicales et usages de l'espace analyzed the role of music in the production of sacred spaces. She is currently working on her next book project, Tuning the World: Acoustics, Aesthetics, Industry, and Global Politics, dedicated to the history of pitch standardization in 19th- and 20th-century Europe and the United States. Her work has appeared or is forthcoming in Past and Present, Sound Studies: an Interdisciplinary Journal, History of the Humanities, Contemporary Music Review, and the Revue de musicologie. She has been a Fondation Thiers fellow, a Fulbright Postdoctoral Fellow and Visiting Scholar at the University of California, Los Angeles, a Dibner Fellow in the History of Science and Technology at the Huntington Library, and a Research Scholar at the Max Planck Institute for the History of Science, Berlin.

\section{Paul Harkins, Edinburgh Napier University}

Paul Harkins is a lecturer in music at Edinburgh Napier University. His research is about the history and uses of sampling technologies and his book, Digital Sampling: The Design and Use of Music Technologies is published by Routledge. Other research interests include copyright, mash-ups, organology, and the music industries. Academic publications include articles in Popular Music, Popular Music \& Society,IASPM@Journal, Journal on the Art of Record Production, and Reseaux. He recently co-edited a special issue of Popular Music on the Anthropocene and is currently working on research projects about digitalization and democratization, and Syco Systems and the distributors of musical instruments. He worked for PRS For Music and as a music publisher before becoming a lecturer and has contributed articles to Product magazine, The Scotsman newspaper, and The Conversation website.

\section{Antoine Hennion, Mines-ParisTech}

Antoine Hennion is a Professor of Sociology at the Centre for the Sociology of Innovation, Mines-ParisTech, PSL Université / CNRS (Paris, France). He entered the CSI in 1974 after a training in engineering at Mines-ParisTech and a parallel training in musicology at La Sorbonne. He extensively published in 
the sociology of culture, medias, music, design, services, and users. Bridging the Actor-Network Theory to Cultural Studies, he has developed an original theoretical framework, mainly drawing on the case of music - an art relying on a range of heterogeneous mediations (bodies, instruments, scores, stages, recordings, medias...). He then developed a pragmatist approach to attachments (things that hold us and that we care for), from taste and practices as music, wine, or sport, to issues about care, aging, and disability. In relation with inquiries on homecare, and presently migrants, he now participates in several research groups or collectives, in order to discuss and enforce new pragmatist forms of inquiries in social sciences: Attachments, a seminar on Fragility; Pragmata, a group gathering philosophers and social scientists on pragmatism; Le PEROU, an activist group working at making migrants a public problem; and Origens Media Lab, a design group promoting an ecological redirection.

Daniel Leech-Wilkinson, King's College London

Daniel Leech-Wilkinson is Emeritus Professor of Music at King's College London. He gained his first degree from London's Royal College of Music (studying harpsichord, organ, and composition) followed by postgraduate studies at King's College London and Clare College, Cambridge. He was a research fellow at Churchill College, Cambridge (1980-84), and Queen's University, Belfast (1984-85), and was a lecturer at Nottingham (1982-83) and Southampton universities (1985-97), before returning to King's College London. As a musicologist he initially researched 14th-century French music (sources, analysis, performance practice), before changing his focus, c. 2000, to the evidence of early recordings in relation to the practice and experience of performance expressivity. He led a project on 'Expressivity in Schubert Song Performance' within the UK Arts \& Humanities Research Council Centre for the History and Analysis of Recorded Music (CHARM, 2004-9), followed by 'Shaping Music in Performance' for the Research Centre for Musical Performance as Creative Practice (2009-14).

Christophe Levaux, University of Liège

Christophe Levaux is a researcher at the University of Liège, Belgium. From 2012 to 2016, he worked as a doctoral fellow (at the University of Liège) in the context of the Interuniversity Attraction Poles Program (IAP - P7/01) Literature and Media Innovation. In the wake of Bruno Latour's or Antoine Hennion's work, he tried to confront Actor-Network-Theory with minimal music historiography. He is the editor of Over and Over: Exploring Repetition in Popular Music, and the author of We Have Always Been Minimalist (University of California Press) or Rage Against the Machine (Densité) as well as numerous articles published in Tacet, Volume!, Revue et Corrigée, Organised Sound, and Rock Music Studies.

Paolo Magaudda, University of Padova

Paolo Magaudda is Assistant Professor in Sociology of Culture and Communication at the Department FISPPA, University of Padova (Italy), where he joined the PaSTIS research unit (Padova Science, Technology \& 
Innovation Studies). The main focus of his work is on the relationship between culture, technology and society, with a specific attention to digital media, communication technologies and music, while his main intellectual fields are science \& technology studies, cultural sociology and sound studies. He has been visiting scholar at the McGill University, Montreal (Canada) and University of California Berkeley (USA). His most recent books are A History of Digital Media. An Intermedia and Global Perspective (with G. Balbi, Routledge, 2018), Vite interconnesse. Pratiche digitali attraverso smartphone, app e piattaforme (in Italian, with M. Drusian and M. Scarcelli, Meltemi 2019) and Gli studi sociali sulla scienza e la tecnologia (in Italian, edited with F. Neresini, Il Mulino, 2020). Among other roles, he is co-editor-in-chief of the journals "Tecnoscienza. Italian Journal of Science \& Technology Studies" (STS Italia) and "Studi Culturali" (Il Mulino).

James Mooney, University of Leeds

James Mooney is Associate Professor of Musicology and Music Technology at University of Leeds, UK. His research focuses on the history of electronic music, electronic musical instruments, and sound technologies, and often involves working collaboratively with musical instrument and science and technology museums. His research on English experimental musician Hugh Davies has been published in peer reviewed journals Organised Sound and the Science Museum Group Journal, and in edited volumes on The Musical Legacy of Karlheinz Stockhausen, Performing Indeterminacy: Experimental Music in Practice (forthcoming), and Rethinking the Musical Instrument (forthcoming). He has also published on technological affordances in music-making (Journal of Music, Technology and Education), noise music (edited volume on Resonances: Noise in Contemporary Music), electronic music on television (Journal of Popular Television, forthcoming), and multi-channel loudspeaker systems in electronic music performance. At University of Leeds, he co-leads the Music, Science and Technology Research Cluster and the History of Technology Reading Group. He currently holds the position Research Associate at the National Science and Media Museum (Bradford, UK), and has previously held positions as Edison Research Fellow at the British Library (2010-11), Research Associate at the Science Museum, London (2013-14 and 2015-16), and AHRC Research Fellow (2015-16).

\section{Trevor Pinch, Cornell University}

Trevor Pinch's main research centers on three areas: the sociology of technology and how users engage with technology; sound studies and music and, in particular, the development of musical instruments and sound objects; markets and the economy with specific attention to the study of selling and persuasion. His most recent book is a series of interview conducted by Italian Media Scholar, Simone Tosini, Entanglements: Conversations on the Human Traces of Science, Technology and Sound, MIT Press 2017. As well as a Professor, he is also a performing musician with the Electric Golem. He was awarded 
an honorary degree by the University of Maastricht in 2012 and received the 2018 J.D. Bernal career award from the Society for Social Studies of Science.

Nick Prior, University of Edinburgh

Nick Prior's work explores the myriad ways technologies are sunk into everyday cultural practices and entangled within social formations, with interests that span urban soundscapes, social theory, and the sociology of music. He is author of a series of articles that explore digital mediations of popular music culture in the post-1980s period, culminating in a monograph, Popular Music, Digital Technology and Society, published by Sage in 2018. He also works with sound and how sound recordings and music composition might be used to enliven our understandings of the multi-sensorial assemblages of cities like Tokyo.

François Ribac, University of Burgundy

François Ribac is a composer of musical theater and senior lecturer at the University of Burgundy (France). His research focuses on popular music and sound reproduction, cultural expertise, and how the arts are facing ecological challenges. His last published book (with Catherine Dutheil-Pessin) is $L a$ Fabrique de la programmation culturelle (La Dispute, 2017).

David Trippett, University of Cambridge

David Trippett is Reader in Music at the University of Cambridge, and a Fellow of Christ's College. His research focuses on 19th-century intellectual history, Richard Wagner, and the philosophy of technology. He is author of Wagner's Melodies (2013), editor and translator of Carl Stumpf, The Origins of Music (2012), and co-edited both The Cambridge Companion to Music in Digital Culture (2019) and Nineteenth-Century Opera and the Scientific Imagination (2019). He currently runs a research project on "Sound and Materialism in the 19th Century," funded by the European Research Council, and has a forthcoming monograph on this topic. In 2019, he also produced the first critical edition of Liszt's opera Sardanapalo for the Neue Liszt Ausgabe (EMB), along with a performing edition for Schott. His research is the recipient of several international awards, including the Alfred Einstein and Lewis Lockwood Prizes (American Musicological Society), the Bruno Nettl Prize (Society for Ethnomusicology), an ASCAP Deems Taylor award, and a Philip Leverhulme Prize.

Patrick Valiquet, University of Edinburgh

Patrick Valiquet is a British Academy Postdoctoral Fellow in Music at the University of Edinburgh. He holds degrees in music and music technology from the University of Oxford, the Royal Conservatoire in The Hague, and McGill University, and has previously held research fellowships from the Institute of Musical Research and the Fonds de Recherche du Quebec Société et Culture. He performs sporadically as an electroacoustic improviser, intermedia artist, and DJ, and since 2015 he also serves as Associate Editor of Contemporary Music Review. 


\section{xiv Contributors}

Basile Zimmermann, University of Geneva

Basile Zimmermann is Senior Lecturer and Director of the Institut Confucius at the University of Geneva in Switzerland, a multidisciplinary research and teaching center on contemporary China. He is the author of Waves and Forms: Electronic Music Devices and Computer Encodings in China (MIT Press, Inside Technology series, 2015), and Popular Humanities or The Culture of Things [in French] (Les Belles Lettres, Paris, forthcoming). His current research projects focus on anthropology of innovation in China and the Middle East. 


\title{
Foreword
}

\section{Sociology and the arts: A few remarks}

\author{
Howard S. Becker
}

The book you are holding in your hands is a tribute to the life and good health of the hybrid field that contains both sociology and the arts. Art, like science, had long been shielded from impartial inspection by sociology, which did not accept conventional aesthetic judgments as the criterion by which we could identify the specific topics a sociological approach to the arts (any and all of them) should cover. The result had been a sociology of music which took as given the canon of Beethoven, Brahms, and Mozart as the core of what a sociology of art had to explain. The sociologists (almost all European, and mostly German or Austrian) who produced this body of work accepted this as too obvious to need argument, let alone proof. In other words, they explained why the composers in that very specific European tradition were as "great" as they were taken to be at the time. These writers did not take other kinds of music - even other components of the standard European orchestral repertoire, like the music of Debussy and Ravelinto account. And they ferociously condemned jazz (which happened to be my kind of music - one of the contributors to this branch of the literature actually referred in print to jazz as "jungle music").

The deepest flaw in these scholars' approach was to take sociology as an adjunct to this imperialistic enterprise rather than the independent science it in fact was and is, the science that seeks to explain the workings of the social organizations that produce what a society calls, and treats as, the world of musical activity. I learned this way of studying any social activity from Everett Hughes. His core idea was that we could best study the people for whom the thing we wanted to study was their daily work. This was a lesson embodied in the sociology of science that Bruno Latour and others later developed at about the same time as others of us were working on a sociology of the arts (or, better put, "artistic activity"). Among other implications of this simple but fruitful idea was the idea that Latour put nicely by saying that the fate of any scientific idea lay in the hands of the people who took it up, took it out of the hands of its inventors. The same thing could be said of any artistic object or event.

Some fateful consequences flow from that. The work of the earlier sociologists of music took for granted something that was part of what a serious sociology of music would investigate, which is the evaluation of the activity the actors in this world engaged in, and its consequences for them and for their subsequent actions, 


\section{xvi Foreword}

for what they did to the work itself. The critics were not separate entities from the music; they were part of the world that made it, an integral part of the process of music making.

But the people who do this critical work are no more important or necessary than the others who do what might seem like mundane ordinary tasks. I can never forget the image of a reed player (I think it was an oboist) watched as he carefully and somewhat despondently picked through a box of 50 reeds in search of one he could use. Which impressed on me the importance of this person who wasn't there in person, just represented by the products, the reeds, he had produced in the hopes of satisfying some forlorn reed player like the one I was watching.

What sociology can add to the "appreciation" of music is an understanding of the contributions of all the people who make the final product possible. And, indeed, what the final product actually is. John Cage taught me this lesson, in his wonderful composition "4'33" - in which a pianist sits in front of a piano keyboard for that length of time, but doesn't touch the keyboard. Cage meant this exercise to teach listeners that every sound that took place in the recital hall during that "silence" was part of the musical experience of the audience. It surely taught me that, and I can't have been the only one.

The contributors to this book have taken that lesson to heart. More specifically, in line with recent works in science and technology studies, they have tried to fully enter into the musical objects, devices, techniques, and theories themselves. The essays contained here show the benefits to our understanding of doing so. Each in its own way, they contribute to our understanding of the larger enterprise that constitutes the world of music. Let them do that for you! 


\title{
Introduction
}

\author{
Antoine Hennion and Christophe Levaux
}

Since its inception as a scholarly discipline in the second half of the 19th century, and for many decades to come, musicology aimed at the scientific study of music, seeking to adopt the same rational standards as the natural sciences. As stated by Friedrich Chrysander introducing the first issue of the seminal Jahrbücher für musikalische Wissenschaft in 1863, musicology was to be treated on the same level as other scientific disciplines. No less than the natural sciences, musicology would reveal facts hidden or inaccessible to the many. Musicology would disclose and state how music history unfolded, identify its great or influential figures, define how their particular influence spread and under what form, and carefully uncover and analyze this form. On the other hand, in the wake of the work of Max Weber (1921) and later Theodor Adorno (1976), sociomusicologists would expose the social and cultural environment where music was produced, how this environment stamped its mark on music creation, and how music impacted society in return.

In other words, music scholars were not to produce or invent content, but to observe and depict a content already there, presumably disregarding their own judgment. This divide between values and facts - the condition of scientificity par excellence - and ultimately between the "human" and the "nonhuman" would find a resonance in another musical field: technology. Musical instruments, and more recently mechanical, electronic, and digital music technologies, were indeed looked at as incredibly sophisticated and elaborate devices, meeting rational and finely measured standards. And this is the way those objects were, until recently, commonly approached in the field of organology: as precisely engineered ones where contingencies and the "human" barely seemed to act.

This divide between science and engineering on the one side and society on the other, which long ran the study of music as in other disciplines, did not prevent cracks or loopholes from appearing here and there, or disputes from erupting between experts, even if these latter were all supposedly to uncover the same truth. Should we remember the debates and controversies concerning-among many other issues - the accompaniment of medieval polyphony (Leech-Wilkinson 2002), Shostakovich's biography (Fay 2004), the esthetic legitimacy of John Cage (Nyman 2013), and the debates on the academic recognition of popular music (Frith 1978, Tagg 1982, Middleton 1990, Hennion and Mignon 1991)? And that 
is not to mention, regarding music technology and quoting Robert Moog himself, that "testing and adjustment are largely a matter of human judgment, rather than the application of rulers and gauges" (cited in Pinch and Trocco 2004: v).

In the study of music, these controversies between incompatible truths would be among the causes of the famous "postmodern turn." In the 1980s, New Musicologists - as they would later be called — stood up against the set of values that permeated traditional musicology, to replace them with other, more inclusive and interdisciplinary ones. Simultaneously, the New Musicology exposed biased positivism by recognizing and even valuing scholarship's inherent subjectivity, at the risk of setting aside the project of a universal knowledge.

Controversies are indeed as old as science. In the 17th century, Newton opposed Descartes on celestial mechanics after Boyle and Hobbes clashed over the existence of vacuums; Lavoisier overturned Stahl's phlogiston theory by founding chemistry a century later; in the 19th century, Pasteur and Pouchet fought over the existence of spontaneous generation, Forbes opposed his colleagues on the abyss, and Darwin refuted everyone on the evolution of species. More recently cold fusion and global warming were objects of heated debates, and at the time this book was being finalized, a jumble of small, bigger, and still open controversies were erupting around the coronavirus pandemic, its nature, severity, medical treatment, and prospects for a vaccine.

The study of scientific controversies, however, is not such a long-established phenomenon. One had to wait until the 1970 s to see a "sociology of scientific knowledge" (SSK) moving away from approaches considering scientific content based on a positivist philosophy of science. This approach aimed to open the "black boxes" of science, explore its contents, and provide - beyond a mere sociology of scientists - sociological accounts of scientific ideas themselves. David Bloor and Barry Barnes's Strong Programme thus urged the study of successful and unsuccessful knowledge claims on the same plan, without privileging the analysis of the one at the expense of the other or invoking social causes for the former and natural ones for the latter (Bloor 1976). For its part, Harry Collins's Empirical Program of Relativism (EPOR) would argue that, as no experiment allows for closing a controversy, it is social mechanisms that impose a single interpretation of facts (Collins 1981). Actor-network theory (ANT) went on to criticize this sociological reductionism: the sociology of scientific knowledge would too heavily rely on social rules and conventions settling scientific controversies. Michel Callon, Bruno Latour, John Law, Arie Rip, Madeleine Akrich, and others would advocate reconsideration of scientific fact and the human, according to the multiplicity of the relations which constitute it (see Latour 1987). This conception led to a rejection of approaches which separate the "human" from the "nonhuman" and, consequently, those which separate politics from science (and technology) or, more broadly, nature from society.

In the late 1980s, Antoine Hennion-closely associated with the development of the actor-network theory articulated by Latour and Callon-was the first to call for a resolution to a dilemma in music studies between considering the musical fact as a reality, neither altered nor determined by experts, and, in a more 
relativistic vein, postulating that the musical fact was above all the fruit of the experts' intimate view (Hennion 1989, 1997, [1993] 2015). Moreover, the reintegration of "nonhuman elements" - scores and texts, sound, instruments, repertoires, staging, concert venues, and media - would allow music to be envisioned "not directly in terms of aesthetic content or social authenticity, but in terms of the way in which, by rejecting certain mediators and promoting others, both are collectively constructed" (Hennion 1997: 432).

Hennion was soon to be followed: in Rationalizing Culture (1995), on the institutionalization of the Parisian musical avant-garde, Georgina Born postulated that meaning was inherent in the social, theoretical, and technological aspects of music and its visual mediations just as in its sound. In Music in Everyday Life (2000), Tia DeNora likewise attempted to illuminate the way in which heterogeneous unions of people and objects are formed, interact, and structure each other. At the same time, Trevor Pinch was adapting the social construction of technology (SCOT) to the study of music and sound. SCOT empirical methods - inherited from the Empirical Programme of Relativism - strove to represent the full complexity of interactions between the different social groups that took part in technological innovation. In 2002, in this same vein, Pinch published Analog Days: The Invention and Impact of the Moog Synthesizer. Pinch opened the way; Karin Bijsterveld and Marten Schulp (2004) would follow its path and delineate new perspectives for organology and sound studies focused on music's scientific and technological mediations.

Since the mid-2000s, this multifaceted field has known a large but scattered number of developments. Whether they address questions of music history, technology, organology, or practices, whether they take their inspiration from SCOT, EPOR, or ANT, they all share the same aim: breaking from the opposition of objectivity versus subjectivity, facts or machines versus humanity, and moving towards a music study where humans, facts, artifacts, techniques, sounds, repertoires, and discourses all interact together. The present book aims for the first time at presenting this approach inspired by science and technology studies, which helps to rethink music. With this particular sociotechnical approach, it is divided into four parts. The first one delves into histories of music, the second scrutinizes instruments, the third approaches technologies, and the last one examines practices.

\section{Histories}

Through different case studies, the first four chapters aim to reveal how musical truths endure controversies, trials, and contingencies before they are reified. Antoine Hennion's 1987 essay “Rameau and Harmony: Can Theory Make Reason of Music?" - revised and translated for the first time in English — acts as a testimony of this pioneering approach in music studies. Here, Hennion delves into Rameau's theory, and in particular the presumed "dissonance" of the seventh. The author shows how theory constitutes an act of production, an operation, and in no way the humble servant of nature. Truth is not a discovery, Hennion states, but 
a construction, which results from a laborious assembly of compromises, which finally produces music. In this same way, in "Sounding Standards: A History Concert Pitch, between Musicology and STS," Fanny Gribenski approaches the note A tuned to 440 hertz, which is now regarded as "natural" and used as the norm for musical performance. For most of music history, Gribenski argues, pitches were fluctuating concepts: countries, cities, and individual musical institutions performed music according to their own tones. But a 1939 treaty marked a crucial turning point in the history of musical practices, putting an end to centuries of instability and dispute in the realm of pitch. Drawing from extensive archival work, Gribenski tracks the creation of concert pitch throughout the second half of the 19th and the first decades of the 20th century, revealing the political and social issues entwined with the creation of a common sonic point of reference.

In the third chapter of this first part, "Is DIY a Punk Invention?: Learning Processes, Recording Devices, and Social Knowledge," François Ribac dissects another fact: it is indeed generally accepted that the "punk revolution" has allowed young people to play music without formal training and make journalism without prior knowledge. Ribac discusses some of the assumptions of this history, and especially the common idea that punk was something completely new which broke all the rules. Going back to a long-range history of DIY practices, he shows that punk is more a visible expression of the place of amateurs in popular culture than a "revolution." He also argues that the circulation of music should be followed not only through bodies, instruments, records, films, hardware, and the web, but also from one area to another, for instance from cinema to music production. In "Secure and Insecure Bases in the Performance of Western Classical Music," Daniel Leech-Wilkinson analyzes another common fact - and practicehere in Western art-music ideology: that performers must be faithful reproducers of composers' intentions. The author asks why practice is so much less varied and more strictly policed in music, to the extent that it behaves more as a historical or worship practice than an artistic one. The training and the policing of professional performance provides musicians with ready-made models, he claims. Moreover, classical performance ideology rests on a collection of delusions, including that the long-dead composer's intentions can be known, and that realizing them will necessarily produce a better result. The author also shows how the exceptionally long and difficult training it requires becomes a mechanism of costly signaling, so expensive that performers cannot afford, nor can they afford for their students, to innovate.

We close this exploration into musical facts and histories with a more epistemological turn in Patrick Valiquet's "Deep Structure: The Generative Subject in Actor-Network Theory and Musicology." Here, the author compares two related attempts to achieve a Chomskian "universal grammar" for music: the "compositional theory" developed by Otto Laske and the "generative theory" developed by Fred Lehrdal and Ray Jackendoff. The author argues that efforts to portray musical behavior as constrained by inborn codes of syntactical competence were not simply borrowings from more powerful disciplines; they enlisted existing musicological concerns, techniques, and technologies in a far broader political 
and epistemological imperative: the drive to establish a scientific basis for liberal discourses of human equality and human rights. In addition to offering new ways of studying musical objects and subjects, STS can help us establish a more rigorous and reflexive understanding of the political and cultural construction of musicological knowledge.

\section{Instruments}

After an exploration into facts, theories, ideas, histories, and concepts, we delve here into the precise mechanics of musical instruments to reveal their human roots. In "Sonic Imaginaries: How Hugh Davies and David Van Koevering Performed Electronic Music's Future," James Mooney and Trevor Pinch develop, through an extensive cross-study, the concept of imaginaries and study its usefulness for a new sociomaterial understanding of musical practices, those of the English experimental musician Hugh Davies and the US synthesizer designer Robert Moog, in particular. Although the basic notion of the imaginary has been occasionally deployed in electronic music histories, the authors suggest, this served a primarily rhetorical function that has tended to boost reductive "pioneer narratives." It also failed to take full account of the sociomateriality within which music-making practices are embedded. Mooney and Pinch develop and extend the concept of the "sonic imaginary," describing and delineating the role of the imaginary in the co-construction of new electronic sound instruments, musical ideologies, and social formations. In "Following the Instruments: The Designers and Users of the Fairlight CMI," Paul Harkins approaches music sellers as "boundary shifters" and "missing masses of technology studies." At the end of the 1970s, Peter Vogel of Fairlight Instruments in Sydney demonstrated a digital synthesizer to Peter Gabriel during the recording of his third studio album. Along with his cousin, Stephen Paine, Gabriel started a distribution company called Syco Systems, which became the sole agent of the Fairlight CMI in the UK. Using interviews with the distributors at Syco Systems, this chapter shows how they connected the engineering worlds of its designers with the musical worlds of its users. It tells a story about how the use of the Fairlight CMI as a sampler rather than a synthesizer was shaped by the marketing strategies of its distributors and conflicted with the original objectives of its designers.

Finally, in "The Interface and Instrumentality of Eurorack Modular Synthesis," Eliot Bates explores the interplay between interface (as the point or surface of contact between the human and the technical) and instrumentality (as a performative property of musical-technical assemblages). His research draws on three years of participant observation within modular synthesis communities, interviews with Eurorack module designers, online discussion of interface aesthetics on popular message forums, and archival research into the longer history of more general forms of technological interface design. Technological aesthetics, the author argues, are not an autonomous property that exists in the world, but rather arise from human sensory and kinesthetic engagement with technological 
objects. In order to frame the affective aspects of these human-technical encounters, Bates utilizes work from sensory anthropology that provides ethnographic accounts of the relation between the material world and human sensory perception and kinesthetics.

\section{Technologies}

From instruments, we scrutinize technology. In "Human Sounds and the Obscenity of Information," David Trippett studies digital voices used by Alexa, Siri, and Cortana. Human conversation, the author shows, is not exclusively driven by data. He explains how the challenge of creating an empathetic AI using not only suitable vocal intonation and speech timing but also modes of vernacular humor and learning has ignited the race to generate mutual empathy between humans on the one hand and the emergent persona of digital assistants on the other. This chapter examines the carefully choreographed sound of digital voices and their relation to human listeners and human interactivity. In the same vein, in "STS Confronts the Vocaloid: Assemblage Thinking with Hatsune Miku," Nick Prior studies the particular case of a singer, Hatsune Miku, who has no vocal chords, always sings in tune, and refers to no one and nothing. Voices, including singing voices, states Prior, are double-coded: they can connect and disconnect, comfort and haunt, unveil and conceal. And they still contain the feint promise of a transhistorical interiority: the "I" as the locus of ultimate meaning and signification. How can STS add to our understandings of vocal mediations when the object under scrutiny then refers to no flesh-andblood singer? This is what the author tries to answer.

To conclude this part on technology, Basile Zimmermann, in "Similarity and Difference in Sound Studies (and elsewhere)," argues that the subfield of sound studies has focused mainly on devices and infrastructures but paid less attention to sound itself, sometimes even describing it as intangible. A sound engineering perspective on sound waves (i.e., audible variations of pressure that air particles take) is then presented by the author and compared with the understandings and uses of the notion of materiality in STS frameworks such as ANT or SCOT. Finally, the framework of waves and forms is introduced as an ontological argument for music studies in the age of the digital.

\section{Practices}

If the humanity of technologies needs to be brought to light, in this last part, we study the materiality of human practices. In "Smartphones, Streaming Platforms, and the Infrastructuring of Digital Music Practices," Paolo Magaudda analyzes the changes that have taken place in music listening practices today as a result of the widespread adoption of smartphones and music streaming services such as Spotify. Based on qualitative data from a study on smartphone use among youth and drawing on an STS theoretical framework on infrastructures, the chapter interprets music listening practices on smartphones as the outcome of 
an ongoing process of "infrastructuring," in which material devices, online platforms, digital data, and shared social music practices have coevolved, embedding today's listeners into a new set of opportunities and constraints. For its part, in "Tracking the Musical Actor-Network: Losing the Meaning of Musical Experience?" François Debruyne investigates the transformations of online music exchange and its consequences for listening ecology and music experience, from a long-term ethnography of a record shop, which became a site of online sale, to the study of the various generations of recommender systems, linked to the rise of streaming music industry. He shows the ease with which the perspectives of science and technology studies allow us to explore the internet's "black boxes" and to trace music's "actor-network". At the same time, he shows the limits of this kind of cognitive routines in helping us understand the meaning of musical practices today. Sometimes, the more we focus on the network of relations and digital black boxes, the less we keep close to social and musical phenomenality, he explains.

Finally, in "Musicalized Images Composing, Playing, Remixing, and Performing Net Art," Jean-Paul Fourmentraux investigates the term net art, which has been used to designate interactive creation designed by, for, and with the internet, as opposed to those more traditional forms of art transferred onto the network. He proposes to distinguish three main types of net art: works of media contamination, of algorithmic generation, and of interactive communication. Here the relationship with technical objects no longer has to do with exploitation or alienation; on the contrary, it functions in the mode of acquaintanceship and contact, and even of play. The observation of this "artistic experience" is based on anthropological or pragmatic excursions into what objects "do" or "cause to be done" to those who create and experience them.

\section{References}

Adorno, Theodor. 1976. Introduction to the Sociology of Music. New York: Seabury Press. Bijsterveld, Karin, and Marten Schulp. 2004. "Breaking into a World of Perfection: Innovation in Today's Classical Musical Instruments." Social Studies of Science 34 (5): 649-74.

Bloor, David. 1976. Knowledge and Social Imagery. London: Routledge.

Chrysander, Friedrich. 1863. "Vorwort und Einleitung." Jahrbücher für musikalische Wissenschaft 1: 9-16.

Collins, Harry M. 1981. "Stages in the Empirical Programme of Relativism." In Knowledge and Controversy: Studies of Modern Natural Science, edited by Harry Collins, special issue of Social Studies of Science 11 (1): 3-10.

Fay, Laurel E. 2004. "Shostakovich versus Volkov : whose Testimony?." in A Shostakovich casebook. edited by Malcolm Hamrick Brown. Bloomington: Indiana University Press.

Frith, Simon. 1978. The Sociology of Rock. Londres: Constable.

Hennion, Antoine. 1989. "An Intermediary between Production and Consumption: The Producer of Popular Music." Science, Technology, \& Human Values 14 (4): 400-424. Ashgate. 


\section{Antoine Hennion and Christophe Levaux}

1997. "Baroque and Rock: Music, Mediators and Musical Taste." Poetics 24 (6): 415-35.

Hennion, Antoine, and Patrick Mignon, eds. 1991. Rock: de l'histoire au mythe. Paris: Anthropos.

Latour, Bruno. 1987. Science in Action: How to Follow Scientists and Engineers through Society. Cambridge, MA: Harvard University Press.

Leech-Wilkinson, Daniel. 2002. The Modern Invention of Medieval Music: Scholarship, Ideology, Performance. Cambridge: Cambridge University Press.

Middleton, Richard. 1990. Studying Popular Music. Milton Keynes: Open University Press.

Nyman, Michael. 2013. Michael Nyman: Collected Writings. Edited by Pwyll ap Siôn. Farnham: Ashgate.

Pinch, Trevor, and Frank Trocco. 2004. Analog Days: The Invention and Impact of the Moog Synthesizer. Rev. ed. Cambridge, MA: Harvard University Press.

Tagg, Philip. 1982. “Analysing Popular Music: Theory, Method and Practice.” Popular Music 2: 37-65.

Weber, Max. 1921. Die rationalen und soziologischen Grundlagen der Musik. Munich: Drei Masken Verlag. 


\section{Introduction}

Adorno, Theodor. . 1976. Introduction to the Sociology of Music. New York: Seabury Press.

Bijsterveld, Karin. , and Marten. Schulp . 2004. Breaking into a World of Perfection: Innovation in Todays Classical Musical Instruments. \$ocial Studies of Science 34 (5): 649674.

Bloor, David. . 1976. Knowledge and Social Imagery. London: Routledge.

Chrysander, Friedrich. . 1863. Dorwort und Einleitung. JahrbCher fĐmusikalische Wissenschaft 1: 9 II6.

Collins, Harry M. 1981. Stages in the Empirical Programme of Relativism. Пh Knowledge and Controversy: Studies of Modern Natural Science, edited by Harry. Collins, special issue of Social Studies of Science 11 (1): 3ா0.

Fay, Laurel E. 2004. Shostakovich versus Volkov : whose Testimony?.in A Shostakovich casebook. edited by Malcolm Hamrick Brown. Bloomington: Indiana University Press.

Frith, Simon. . 1978. The Sociology of Rock. Londres: Constable.

Hennion, Antoine. . 1989. An Intermediary between Production and Consumption: The Producer of Popular Music.\$science, Technology, \& Human Values 14 (4): 400424.

Hennion, Antoine. . [1993] 2015. The Passion for Music: A Sociology of Mediation. Burlington, VT: Ashgate.

8 Hennion, Antoine. . 1997. Blaroque and Rock: Music, Mediators and Musical Taste. [Poetics 24 (6): 415435.

Hennion, Antoine. , and Patrick. Mignon, eds. 1991. Rock: de l冋istoire au mythe. Paris:

Anthropos.

Latour, Bruno. . 1987. Science in Action: How to Follow Scientists and Engineers through

Society. Cambridge, MA: Harvard University Press.

Leech-Wilkinson, Daniel. . 2002. The Modern Invention of Medieval Music: Scholarship, Ideology, Performance. Cambridge: Cambridge University Press.

Middleton, Richard. . 1990. Studying Popular Music. Milton Keynes: Open University Press. Nyman, Michael. . 2013. Michael Nyman: Collected Writings. Edited by Pwyll ap Sin Farnham: Ashgate.

Pinch, Trevor. , and Frank. Trocco . 2004. Analog Days: The Invention and Impact of the Moog Synthesizer. Rev. ed. Cambridge, MA: Harvard University Press.

Tagg, Philip. . 1982. Analysing Popular Music: Theory, Method and Practice. Popular Music 2: 3765 .

Weber, Max. . 1921. Die rationalen und soziologischen Grundlagen der Musik. Munich: Drei Masken Verlag.

\section{Rameau and harmony}

Callon, Michel. , and Bruno. Latour . 2012. Bour une sociologie relativement exacte. In La Fin de la socitilDblats contemporains autour dUn concept classique, edited by Jonathan. Roberge , Yan. Snchal , and Stphane. Vibert, 3966. Outremont, QC: Athnia.

Chailley, Jacques. . 1965. Bameau et la thørie musicale. ma Revue Musicale 260: 6595.

Dubois, Thסdore. . 1921. Trait@lbarmonie: Thørie et pratique. Paris: Heugel.

Girdlestone, Cuthbert. . 1969. Jean-Philippe Rameau: His Life and Work. New York: Dover.

Hennion, Antoine. . 1987. Bameau et Illarmonie: Comment avoir raison de la musique? [h JeanPhilippe Rameau, edited by J. de La Gorce , 393405. Paris-Genve: Champion-Slatkine.

Hennion, Antoine. , and JoEMarie. Fauquet . 2001. Authority as Performance: The Love of Bach in Nineteenth-Century France. Poetics 29: 7588.

Hennion, Antoine. , and Bruno. Latour . 1993. Objet de science, objet dart: Note sur les limites de lanti-ftichisme. \$ociologie de IArt 6: 5DA.

Hennion, Antoine. , and Bruno. Latour . 2003. Bow to Make Mistakes on So Many Things at Onceand Become Famous for It. Th Mapping Benjamin: The Work of Art in the Digital Age, edited by Hans Ulrich. Gumbrecht and Michael. Marrinan , 9197. Stanford, CA: Stanford University Press.

Hennion, Antoine. , Franठise. Martinat, and Jean-Pierre. Vignolle , eds. 1983. Les

Conservatoires et leurs खes. Paris: La Documentation Franalse.

Kintzler, Catherine. . 1983. Jean-Philippe Rameau: Splendeur et naufrage de Ielsthtique du plaisir lige classique. Paris: Le Sycomore.

Rameau, Jean-Philippe. . 1722. Trait[le 旧armonie rđluite [ses principes naturels. Paris: Ballard. 
Rameau, Jean-Philippe. . 1737. Gration Harmonique. Paris: Prault fils.

Rameau, Jean-Philippe. . 1754. Observations sur notre instinct pour la musique. Paris: Prault fils, Lambert, Duchesne.

25 Rameau, Jean-Philippe. . 1971. Treatise on Harmony. Translation (of Rameau 1722) by Philip Gossett. New York: Dover.

Rameau, Jean-Philippe. . 1974. Harmonic Generation. Translation (of Rameau 1737) by

Deborah Hayes. Ann Arbor, MI: University Microfilms.

Reber, Henri. . 1862. Trait@'Harmonie. Paris: Colombier.

Riemann, Hugo. . 1896. Harmony Simplified, or the Theory of the Tonal Functions of Chords.

Translated from the German. London: Augener.

\section{Sounding standards}

Berlioz, Hector. . 1858. ¿e diapason. Journal des dblats, September 29, 1858, 1Д]

Bijsterveld, Karin. . 2008. Mechanical Sound: Technology, Culture, and Public Problems of Noise in the Twentieth Century. Cambridge, MA: MIT Press.

Bijsterveld, Karin. , Efje. Cleophas, Stefan. Krebs, and Gijs. Mom . 2013. Sound and Safe: A History of Listening behind the Wheel. Oxford: Oxford University Press.

Blaikley, D. J. (David James). Memorandum on the Pitch Army Bands. N.d. London: Boosey and Hawkes (third edition, 1909 for the first edition).

Brunsson, Nils. , and Beigt. Jacobson, eds. 2000. A World of Standards. Oxford: Oxford University Press.

Brunnsson, Nils. , Andreas. Rasche, and David. Seidl . 2012. The Dynamics of

Standardization: Three Perspectives on Standards in Organization Studies. Organization

Studies 33 (56): 613632.

Cavaill-Coll, Aristide. . 1859. De la dtermination du ton normal ou du diapason pour laccord des instruments de musique.mAmi de la Religion et du Roi, February 5, 1859, $301 \mathrm{Bl} 3$.

Deagan, John C. 1918. $\mathbb{A}=440$ Pitch Adopted: Pitch versus Temperature. Musical Quarterly 4 (4): 587592.

Erench Pitch Adopted for Pianos by the MTNA.1886 (November 20). The Music Trade Review 10 (8): 118.

Giacomelli, Adolphe. . 1856. Slocitlles fabricants de pianos. Sance du 9 juin. Unit[lu diapason. $\square$ La France musicale 20 (24): 1 ]

Gracyk, Tim. , and Frank. Hoffmann . 2008. Popular American Recording Pioneers: 1895ா925. London: Routledge.

Gribenski, Fanny. , and Edward. Gillin . Forthcoming, 2021. Mlore French than the FrenchपThe Politics of Musical Standardization in Nineteenth-Century France and Britain. Past and Present 251.

Haynes, Bruce. . 2002. A History of Performing Pitch: The Story of A.manham, MD: Scarecrow Press.

Jackson, Myles. . 2006. Harmonious Triads: Physicists, Musicians, and Instrument Makers in Nineteenth-Century Germany. Cambridge, MA: MIT Press.

Kaiserlich-KWigliches Ministerium fĐCultus und Unterricht . 1885. Beschlsse und Protokolle der Internationalen Stimmton Conferenz in Wien 1885. Vienna: Kaiserlich-KViglicher SchulbCher. Labouret, Tristan. . 2018. [addoption du diapason normal en France dans les annels 1860: Les formations instrumentales एpreuve de la standardisation. Musique-Images-Instruments 17. Notes et documents: 300B25.

Lampland, Martha. , and Susan Leigh. Starr . 2009. Standards and Their Stories: How Quantifying, Classifying, and Formalizing Practices Shape Everyday Life. Ithaca, NY: Cornell University Press.

Lissajous, Jules-Antoine. . 1855. Dote sur Iएखation progressive du diapason des orchestres depuis Louis XIV jusqu[nos jours et sur la nCessitdadopter un diapason normal et 46universel. Bulletin de la SocitlliEncouragement pour I[ndustrie Nationale 54 (2): 29397.

MacPherson, Bruce. , and James. Klein . 1995. Measure by Measure: A History of New England Conservatory from 1867. Boston, MA: Trustees of New England Conservatory of Music.

Mazzola, Sandy Raymond. . 1984. When Music is Labor: Chicago Bands and Orchestras and the Origins of the Chicago Federation of Musicians, 1880प902. PhD diss., Northern Illinois University. 
Meerens, Charles. . 1873. Le Diapason et la notation musicale simplifiel Paris: Schott.

Mills, Mara. . 2011. Deafening: Noise and the Engineering of Communication in the Telephone System.Grey Room 43: 118П443.

Mills, Mara. . 2018. Decibel. Wh Handbuch Sound. GeschichteBegriffeđnstze, edited by Daniel.

Morat and Hansjakob. Ziemer , 5256. Stuttgart: J. B. Metzler Verlag.

Minist尼 dtat . 1859. Rapport et arrt\$̈pour l'tablissement en France d'un diapason musical uniforme. Paris: Imprimerie impriale.

Mukerji, Chandra. . 2009. Impossible Engineering: Technology and Territoriality on the Canal du Midi. Princeton, NJ: Princeton University Press.

Radano, Ronald. , and Tejumola. Olaniyan . 2016. Audible Empire: Music, Global Politics, Critique. Durham, NC: Duke University Press.

Richardson, Edward G. 1940. The International Standard of Musical Pitch. Dournal of the Royal Society of Arts 88 (4570): 851864.

Schaffer, Simon. . 2018. [a nouvelle dfinition du kilo est une rVolution thסlogique. Me Monde, November 13, 2018. https://www.lemonde.fr/sciences/article/2018/11/12/la-nouvelle-definitiondu-kilo-est-une-revolution-theologique_5382601_1650684.html.

Standard Pitch Adopted by the Piano Manufacturers[Association of New York and Vicinity, Friday, November 6, 911. Fuller\$Address. 1891. The Musical Courier, November 11, 1891, 549551.

Sterne, Jonathan. . 2003. The Audible Past: Cultural Origins of Sound Reproduction. Durham, NC: Duke University Press.

Sterne, Jonathan. . 2012. MP3: The Meaning of a Format. Durham, NC: Duke University Press. Thompson, Emily. . 2002. The Soundscape of Modernity: Architectural Acoustics and the Culture of Listening in America, 1900[933. Cambridge, MA: MIT Press.

Timmermans, Stefan. , and Steven. Epstein . 2010. A World of Standards but not a Standard World: Toward a Sociology of Standards and Standardization. RAnnual Review of Sociology 36 (2): 6989.

Yates, JoAnn. , and Craig N. Murphy . 2019. Engineering Rules: Global Standard Setting since 1880. Baltimore, MD: Johns Hopkins University Press.

\section{Is DIY a punk invention?}

Akrich, Madeleine. . 1992. The De-Scription of Technical Objects. पh Shaping

Technology/Building Society: Studies in Sociotechnical Change, edited by Wiebe E. Bijker and John. Law , 206R24. Cambridge, MA: MIT Press.

Assayas, Michka. , ed. 2000. Dictionnaire du Rock: Blues, Country, Folk, Pop, Reggae, Rock Indpendant, Soul. Paris: Robert Laffont-Bouquins.

Babiuk, Andy. . 2001. Beatles Gear: All the Fab FourEInstruments from Stage to Studio.

Lanham: Backbeat Books.

Bennett, H. Stith. . 1980. On Becoming a Rock Musician. Amherst, MA: University of

Massachusetts Press.

Bijker, Wiebe E. , and John. Law , eds. 1992. Shaping Technology/Building Society: Studies in Sociotechnical Change. Cambridge, MA: MIT Press.

Borwick, John. 1990. Microphones: Technology and Techniques. Waltham, MA: Focal Press.

Braun, Hans-Joachim. , ed. 2000. Music and Technology in the Twentieth Century. Baltimore, MD: Johns Hopkins University Press.

Callon, Michel. , Pierre. Lascoumes, and Yannick. Barthe . 2009. Acting in an Uncertain World: An Essay on Technical Democracy. Cambridge, MA: MIT Press.

Casey, Susan. . 1997. Women Invent! Two Centuries of Discoveries that Have Shaped Our World. Chicago, IL: Chicago Review Press.

Castagnac, Gilles. , and Frandis. Ribac . 2018. Daissance dđhe politique du rock. In Simon Frith: Une sociologie des musiques populaires, edited by Simon. Frith , 111[27. Dijon: Presses du Rel/Labex.

Chanan, Michael. . 1995. Repeated Takes: A Short History of Recording and Its Effects on Music. London: Verso.

Charters, Samuel. . 2008. A Trumpet around the Corner. Jackson, MS: University Press of Mississippi.

Collins, Harry. . 2010. Tacit and Explicit Knowledge. Chicago, IL: University of Chicago Press.

64 Collins, Harry. , and Robert. Evans . 2007. Rethinking Expertise. Chicago, IL: University of Chicago Press. 
Cook, Nicholas. , Eric. Clarke, Daniel. Leech-Wilkinson, and John. Rink, eds. 2009. The Cambridge Companion to Recorded Music. Cambridge: Cambridge University Press.

Crosby, Bing. . 2003. Call Me Lucky, Bings]CrosbyEOwn Story. As told to Pete Martin. Boston, MA: Da Capo Press.

Danchin, Sebastian. . 2004. Elvis Presley; ou, la revanche du Sud. Paris: Fayard.

DeNora, Tia. . 2000. Music in Everyday Life. New York: Cambridge University Press.

Devine, Kyle. . 2013. A Mysterious Music in the Air. Popular Music History 8 (1): 528.

Douglas, Susan J. 2004. Listening In: Radio and the American Imagination. Minneapolis, MN:

University Press of Minnesota.

Doyle, Peter. . 2005. Echo and Reverb: Fabricating Space in Popular Music Recording,

1900प1960. Middletown, CT: Wesleyan University Press.

Eargle, John. . 2005. The Microphone Book. Oxford: Focal Press.

Edgerton, David. . 2011. Shock of the Old: Technology and Global History since 1900. London: Profile Books.

Eisenberg, Evan. . 2005. The Recording Angel: Music, Records, and Culture from Aristotle to Zappa. London: Yale University Press.

Emerick, Geoff. , and Howard. Massey . 2007. Here, There and Everywhere: My Life Recording the Music of the Beatles. New York: Gotham Books.

Escott, Colin. , and Martin. Hawkins . 1991. Good RockinTonight; Sun Records and the Birth of Rock IIRoll. New York: St. Martins Press.

Frith, Simon. . 1992. The Industrialization of Popular Music. Wh Popular Music and

Communication, edited by James. Lull , 4974. London: SAGE.

Gardey, Delphine. . 2001. La dactylographe et lexpditionnaire: Histoire des employs]de bureau, 18901930. Paris: Belin.

Gelatt, Roland. . 1977. The Fabulous Phonograph, 1877ㅍ77, 2nd ed. London: Cassell.

Gelbart, Matthew. . 2007. The Invention of Eolk Music and Art Music Emerging Categories from Ossian to Wagner. Cambridge: Cambridge University Press.

Gertner, Jon. . 2012. The Idea Factory: Bell Labs and the Great Age of American Innovation.

New York: Penguin.

Giddins, Gary. . 2001. Bing Crosby, a Pocketful of Dreams: The Early Years, 1903펴0.

Boston, MA: Little, Brown.

Green, Lucy. . 2001. How Popular Musicians Learn, a Way Ahead for Music Education.

Aldershot: Ashgate.

Guralnick, Peter. . 1994. Last Train to Memphis: The Rise of Elvis Presley. London: Abacus.

Hagstrom Miller, Karl. . 2010. Segregating Sound: Inventing Folk and Pop Music in the Age of Jim Crow. Durham, NC: Duke University Press.

Hebdige, Dick. . 2002. Subculture: The Meaning of Style. London: Taylor.

Hein, Fabien. . 2012. Do It Yourself! Autodtermination et culture punk. Lyon: Le Passager Clandestin.

Hennion, Antoine. . 2015. The Passion for Music: A Sociology of Mediation. Surrey: Ashgate. Hennion, Antoine. , Sophie. Maisonneuve, and Emilie. Gomart . 2000. Figures de lamateur, formes, objets, pratiques de lamour de la musique aujourdnui. Paris: La Documentation Franalse.

Hilliard, Robert L. , and Michael C. Keith . 1997. The Broadcast Century: A Biography of American Broadcasting. Boston, MA: Focal Press.

65 Hilmes, Michele. . 1997. Radio Voices: American Broadcasting, 1922 1952 . Minneapolis, MN: University of Minnesota Press.

Johnson, Bruce. . 2000. The Inaudible Music: Jazz, Gender and Australian Modernity. Sydney, NSW: Currency Press.

Jorgensen, Ernst. . 1998. Elvis Presley: A Life in Music; The Complete Recording Sessions. New York: St. Martins]Press.

Latour, Bruno. . 1993. We Have Never Been Modern. Cambridge, MA: Harvard University Press.

Lockheart, Paula. . 2003. A History of Early Microphone Singing, 1925ா939: American Mainstream Popular Singing at the Advent of Electronic Microphone Amplification. Popular Music and Society 26 (3): 367385.

MacDonald, Ian. . 1997. Revolution in the Head: The Beatles Records and the Sixties. London: Pimlico.

Maisonneuve, Sophie. . 2009. L[nvention du disque 1877[1949: Genße de IUsage des mđlas musicaux contemporains. Paris: ditions des archives contemporaines.

Marcus, Greil. . 1975. Mystery Train: Images of America in Rock nlRoll Music. Boston, MA: Dutton. 
Marcus, Greil. . 1989. Lipstick Traces: A Secret History of the Twentieth Century. Cambridge, MA: Harvard University Press.

McCracken, Allison. . 2015. Real Men DontSing: Crooning in American Culture. Durham, NC: Duke University Press.

Maddel, CClle. . 1994. Histoire de la radio des annels trente. Paris: Anthropos Economica.

Millard, A. J. 1995. America on Record. A History of Recorded Sound. Cambridge: Cambridge University Press.

Northrop Moore, Jerrold. . 1999. Sound Revolutions. A Biography of Fred Gaisberg, Founding Father of Commercial Sound Recording. London: Sanctuary.

Oldenziel, Ruth. . 2004. Making Technology Masculine: Men, Women, and Modern Machines in America, 1870प1945. Amsterdam: Amsterdam University Press.

Oldenziel, Ruth. , and Mikael. Hrd . 2013. Consumers, Tinkerers, Rebels: The People Who Shaped Europe. New York: Palgrave Macmillan.

Oudshoorn, Nelly. , and Trevor. Pinch, eds. 2003. How Users Matter: The Co-Construction of Users and Technology. Cambridge, MA: MIT Press.

Peterson, Richard. 1997. Creating Country Music: Fabricating Authenticity. Chicago, IL: University of Chicago Press.

Pleasants, Henry. . 1974. The Great American Popular Singers. New York: Simon \& Schuster. Polanyi, Michael. . 1983. The Tacit Dimension. Gloucester, MA: Peter Smith.

Ribac, Frandis. . 2004. Lavaleur de rock. Paris: La Dispute.

Ribac, Franछis. . 2005. Sur limportance des disques et du recording dans la musique populaire et la techno. Mouvements 42: 5460 .

Ribac, Franठis. . 2012. Quand lamateur rend le numrique analogique: Lexemple des musiques populaires. Revue dÆnthropologie des connaissances 6 (3): 717741.

Ribac, Franסis. . 2014. [apprentissage des musiques populaires[Une approche comparatiste de la construction des genres. In Pour en finir avec la fabrique des garons, vol. 2, edited by Sylvie. Ayral and Yves. Raibaud , 131प46. Pessac: ditions MSH dAquitaine.

Ribac, Franठis. . 2019. Cinema as Social Knowledge. The Case of the Beatles in the Studio. In The Oxford Handbook of Sound \& Imagination, edited by Mark. Grimshaw, Mads. WaltherHansen, and Martin. Knakkergaard , 565585. Oxford: Oxford University Press.

66 Savage, Jon. . 1992. EnglandEDDreaming: Sex Pistols and Punk Rock. London: Faber and Faber.

Schmidt Horning, Susan. . 2002. Erom Polka to Punk: Growth of an Independent Recording Studio, 1934 [1977. In Music and Technology in the Twentieth Century, edited by Hans-Joachim. Braun, 136 147. Baltimore, MD: Johns Hopkins University Press.

Schmidt Horning, Susan. . 2013. Chasing Sound: Technology, Culture, and the Art of Studio Recording from Edison to the LP. Baltimore, MD: Johns Hopkins University Press.

Serres, Michel. . 1980. Le parasite. Paris: Pluriel.

Serres, Michel. . 1999. Variations sur le corps. Paris: Le Pommier.

Silverstone, Roger. , and Eric. Hirsch , eds. 1994. Consuming Technologies: Media and Information in Domestic Spaces. London: Routledge.

Star, Susan Leigh. , and James R. Griesemer . 1989. [nstitutional Ecology, Translationsaand Boundary Objects: Amateurs and Professionals in BerkeleysMuseum of Vertebrate Zoology. $\square$ Social Studies of Science 19 (3): 387420.

Sterne, Jonathan. . 2003. The Audible Past. Cultural Origins of Sound Reproduction. Durham, NC: Duke University Press.

Suisman, David. , and Susan. Strasser , eds. 2010. Sound in the Age of Mechanical Reproduction. Philadelphia, PA: University of Pennsylvania Press.

Taylor, Timothy Dean. , Mark. Katz , and Tony. Grajeda, eds. 2012. Music, Sound, and Technology in America: A Documentary History of Early Phonograph, Cinema, and Radio. Durham, NC: Duke University Press.

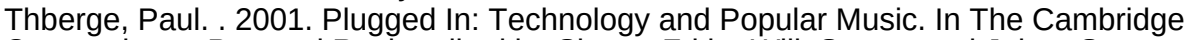

Companion to Pop and Rock, edited by Simon. Frith, Will. Straw, and John . Street , 325. New York: Cambridge University Press.

Tosches, Nick. . 1996. Country: The Twisted Roots of Rock nIRoll. Boston, MA: Da Capo Press. Tourn§, Ludovic. . 2008. Musique! Du phonographe au MP3. Paris: Autrement.

Tunzi, Joseph A. 1993. Elvis Sessions. The Recorded Music of Elvis Aron Presley, $1953 \mathbb{1} 977$. Chicago, IL: Jat Productions.

Ward, Ed. , Geoffrey. Stokes, and Ken. Tucker . 1986. Rock of Ages. The Rolling Stone History of Rock \& Roll. New York: Rolling Stone Press/Summit Books. 


\section{Secure and insecure bases in the performance of Western classical music}

Ainsworth, Mary D.S. 1985. Attachments across the Life Span. ஐBulletin of the New York Academy of Medicine 61: 7928112.

Bowlby, John. . 1982. Attachment and Loss. Vol. 1, Attachment. 2nd ed. New York: Basic Books.

Chaffin, Roger. , and Anthony F. Lemieux . 2004. General Perspectives on Achieving Musical Excellence. In Musical Excellence: Strategies and Techniques to Enhance Performance, edited by Aaron. Williamon , 19B9. Oxford: Oxford University Press.

Clarke, Eric. , Tia. DeNora, and Jonna. Vuoskoski . 2015. Dusic, Empathy and Cultural Understanding. Whysics of Life Reviews 15: 6188.

Cox, Arnie. . 2001. The Mimetic Hypothesis and Embodied Musical Meaning. Musicae Scientiae 5 (2): 195209.

Cox, Arnie. . 2011. Embodying Music: Principles of the Mimetic Hypothesis. Music Theory Online 17 (2). http://www.mtosmt.org/issues/mto.11.17.2/mto.11.17.2.cox.html.

Cox, Arnie. . 2016. Music and Embodied Cognition: Listening, Moving, Feeling, and Thinking. Bloomington, IN: Indiana University Press.

Cumming, Naomi. . 2001. The Sonic Self: Musical Subjectivity and Signification. Bloomington, IN: Indiana University Press.

Dissanayake, Ellen. . 2000. Antecedents of the Temporal Arts in Early Mother-Infant Interaction. $\square$ In The Origins of Music, edited by Nils L. Wallin , Bjm. Merker , and Steven . Brown , 389410. Cambridge, MA: MIT Press.

Dissanayake, Ellen. . 2008. f Music Is the Food of Love, What about Survival and Reproductive Success? Musicae Scientiae (special issue) 12 (1): 169 प95.

Gabrielsson, Alf. . 2011. Strong Experiences with Music. Oxford: Oxford University Press.

Gaines, Jane M. 1991. Contested Culture: The Image, the Voice and the Law. Chapel Hill, NC: University of North Carolina Press.

85 Gallese, Vittorio. . 2017. Disions of the Body: Embodied Simulation and Aesthetic

Experience. RAisthesis: Pratiche, linguaggi e saperi dellestetico 10 (1): 4150.

Gomart, milie. , and Antoine. Hennion . 1999. A Sociology of Attachment: Music Amateurs, Drug Users. The Sociological Review 47 (1): 220247.

Granqvist, Pehr. , and Lee A. Kirkpatrick . 2013. Beligion, Spirituality, and Attachment.『n APA Handbook of Psychology, Religion, and Spirituality, vol. 1, Context, Theory, and Research, edited by Kenneth I. Pargament, Julie J. Exline, and James W. Jones , 1391155. Washington, DC: American Psychological Association.

Grier, James. . 1995. Musical Sources and Stemmatic Filiation: A Tool for Editing Music. $\square$ Journal of Musicology 13 (1): 73प02.

Hatten, Robert S. 2018. A Theory of Virtual Agency for Western Art Music. Bloomington, IN: Indiana University Press.

Hennion, Antoine. . 2017. Attachments, You Say? How a Concept Collectively Emerges in One Research Group.Dournal of Cultural Economy 10 (1): $112 \mathbb{1 2 1 .}$

Hoff, Eva V. 2005. שnaginary Companions, Creativity, and Self-Image in Middle Childhood. $\square$ Creativity Research Journal 17 (2B): 167180.

Imberty, Michel. . 1997. Dan One Seriously Speak of Narrativity in Music? Пn Proceedings of the

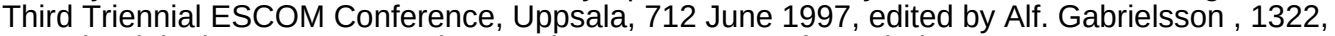
French original on 23BD. Uppsala, Sweden: Department of Psychology.

Johnson, Julian. . 2002. Who Needs Classical Music? Cultural Choice and Musical Values. Oxford: Oxford University Press.

Kingsbury, Henry. . 1988. Music, Talent, and Performance: A Conservatory Cultural System. Philadelphia, PA: Temple University Press.

Koestenbaum, Wayne. . 1993. The Queen's Throat: Opera, Homosexuality and the Mystery of Desire. New York: Simon \& Schuster.

Krueger, Joel. . 2013. Empathy, Enaction, and Shared Musical Experience: Evidence from Infant Cognition. In The Emotional Power of Music: Multidisciplinary Perspectives on Musical Arousal, Expression, and Social Control, edited by Tom. Cochrane, Bernadino. Fantini , and Klaus R. Scherer , 177푸. Oxford: Oxford University Press.

Kuhn, Thomas. . 1962/1996. The Structure of Scientific Revolutions. Chicago, IL: University of Chicago Press.

Leech-Wilkinson, Daniel. . 2002. The Modern Invention of Medieval Music. Cambridge:

Cambridge University Press.

Leech-Wilkinson, Daniel. . 2006. Bortamento and Musical Meaning.Dournal of Musicological

Research 25 (34): 233261. 
Leech-Wilkinson, Daniel. . 2009a. The Changing Sound of Music: Approaches to the Study of Recorded Musical Performances. London: CHARM.

http://www.charm.kcl.ac.uk/studies/chapters/intro.html.

Leech-Wilkinson, Daniel. . 2009b. Becordings and Histories of Performance Style. In The Cambridge Companion to Recorded Music, edited by Nicholas. Cook, Eric. Clarke, Daniel. Leech-Wilkinson, and John. Rink , 246262. Cambridge: Cambridge University Press.

Leech-Wilkinson, Daniel. . 2010. Listening and Responding to the Evidence of Early TwentiethCentury Performance. Dournal of the Royal Musical Association (special issue) 135 (1): 4562.

Leech-Wilkinson, Daniel. . 2011. Mlaking Music with Alfred Cortot: Ontology, Data, Analysis. ஐh Gemessene InterpretationDomputergestØte AuffGrungsanalyse im Kreuzverhøder Disziplinen, edited by Heinz. Loesch and Stefan. Weinzierl, 129『44. Mainz: Schott.

Leech-Wilkinson, Daniel. . 2016. Classical Music as Enforced Utopia. Aarts and Humanities in Higher Education 15 (34): 325336.

86 Leech-Wilkinson, Daniel. . 2018. Musical Shape and Feeling. Th Music and Shape, edited by Daniel. Leech-Wilkinson and Helen M. Prior , 358382. Oxford: Oxford University Press.

Leech-Wilkinson, Daniel. . 2020a. Challenging Performance: Classical Music Performance Norms and How to Escape Them. https://challengingperformance.com/the-book/.

Leech-Wilkinson, Daniel. . 2020b. Moral Judgement in Response to Performances of Western Art Music. In Remixing Music Studies: Essays in Honour of Nicholas Cook, edited by Ananay. Aguilar, Eric. Clarke, Ross. Cole, and Matthew. Pritchard . Abingdon: Routledge, 91m1. Malloch, Stephen. , and Colwyn. Trevarthen , eds. 2009. Communicative Musicality: Exploring the Basis of Human Companionship. Oxford: Oxford University Press.

McAndrew, Francis T. 2019. Dostly Signaling Theory. Encyclopedia of Evolutionary

Psychological Science, edited by Todd K. Shackelford and Viviana A. Weekes-Shackelford .

Cham, Switzerland: Springer Nature. doi: 10.1007/978-3-319-16999-6_3483-1.

Molnar-Szakacs, Istvan. , Vanya G. Assuied, and Katie. Overy . 2011. Shared Affective Motion Experience (SAME) and Creative, Interactive Music Therapy. In Musical Imaginations:

Multidisciplinary Perspectives on Creativity, Performance and Perception, edited by David. Hargreaves, Dorothy. Miell , and Raymond. MacDonald , 313331. Oxford: Oxford University Press.

Nelissen, Rob M. A. , and Marijn H. C. Meijers . 2011. Social Benefits of Luxury Brands as Costly Signals of Wealth and Status. EFvolution and Human Behavior 32 (5): 343355.

Nettl, Bruno. . 1995. Heartland Excursions: Ethnomusicological Reflections on Schools of Music. Urbana, IL: University of Illinois Press.

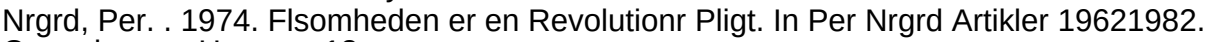

Copenhagen: Hansen, 1B.

Papoulek, HanuЦ Mechthild. Papoulek, and David. Symmes . 1991. The Meanings of Melodies in Motherese in Tone and Stress Languages. Whfant Behavior and Development 14 (4), 415440.

Parncutt, Richard. , and Annekatrin. Kessler . 2006. Busik als virtuelle Person. Ih Musik als $\square$ Ausgewhite Betrachtungsweisen, edited by Rudolf. Flotzinger, 952. Vienna: Sterreichische Akademie der Wissenschaften.

Peters, Deniz. . 2015. Musical Empathy, Emotional Co-Constitution, and the Musical Other. $\square$ Empirical Musicology Review 10 (1). http://emusicology.org/article/view/4611/4159.

Philip, Robert. . 1992. Early Recordings and Musical Style: Changing Tastes in Instrumental Performance, 1900 1950. Cambridge: Cambridge University Press.

Schtz, Alfred. . 1951. Mlaking Music Together: A Study in Social Relationship.\$ocial Research 18 (1): 7697.

Slttebrekk, Sigurd. , and Tony. Harrison . 2010. Chasing the Butterfly: Recreating Grieg\$1903 Recordings and Beyond. http://www.chasingthebutterfly.no/.

Small, Christopher. . 1998. Musicking: The Meanings of Performing and Listening. Middletown, CT: Wesleyan University Press.

Smith, Eric A. , and Rebecca L.B. Bird . 2000. Turtle Hunting and Tombstone Opening: Public Generosity as Costly Signaling. Evvolution and Human Behavior 21 (4): 245261.

Sosis, Richard. , and Eric R. Bressler . 2003. Cooperation and Commune Longevity: A Test of the Costly Signaling Theory of Religion.Cross-Cultural Research: The Journal of Comparative Social Science 37 (2), 211239.

Stern, Daniel. . 2010. Forms of Vitality: Exploring Dynamic Experience in Psychology, the Arts, Psychotherapy, and Development. Oxford: Oxford University Press.

Taruskin, Richard. . 1995. Text and Act: Essays on Music and Performance. Oxford: Oxford University Press.

87 Taruskin, Richard. . 2009. The Danger of Music and Other Anti-Utopian Essays. Berkeley, CA: University of California Press.

Tomlinson, Gary. . 2015. A Million Years of Music: The Emergence of Human Modernity. New York: Zone Books. 
Trehub, Sandra. . 2000. Buman Processing Predispositions and Musical Universals. In The Origins of Music, edited by Nils L. Wallin , Bjm. Merker, and Steven . Brown , 427 448.

Cambridge, MA: MIT Press.

Trehub, Sandra E. , and Laurel J. Trainor . 1998. Singing to Infants: Lullabies and Play Songs. $\square$ Advances in Infancy Research 12: 43ד7.

Trehub, Sandra E. , Anna M. Unyk, and Laurel J. Trainor . 1993. Adults Identify Infant-Directed Music across Cultures. Пnfant Behavior and Development 16 (2): 193211.

Unyk, Anna M. , Sandra E. Trehub , Laurel J. Trainor , and E. Glenn. Schellenberg . 1992.

Lullabies and Simplicity: A Cross-Cultural Perspective.Psychology of Music 20 (1): 1528.

Wagner, Izabela. . 2015. Producing Excellence: The Making of Virtuosos. New Brunswick, NJ:

Rutgers University Press.

Watt, Roger J. , and Rois凹 L. Ash . 1998. A Psychological Investigation of Meaning in Music. $\square$ Musicae Scientiae 2: 3353.

\section{Deep structure}

Adkins, Brent. . 2016. Who Thinks Abstractly? Deleuze on Abstraction. Dournal of Speculative Philosophy 30 (3): 352360.

Althusser, Louis. . 1969. For Marx. Translated by Ben. Brewster . London: Allen Lane.

Althusser, Louis. . 2008. On Ideology. London: Verso.

Aroui, Jean-Louis. , and Anne. Zribi-Hertz . 2002. [n Memoriam Nicolas Ruwet (19332001). me franals moderne: Revue de linguistique franalse 70 (1): $109 \mathbb{1} 1$.

Balibar, tienne. . 2005. Structuralism: A Destitution of the Subject?Differences 14 (1): 17

Barsky, Robert F. 1997. Noam Chomsky: A Life of Dissent. Cambridge, MA: MIT Press.

Bates, Eliot. . 2018. Actor-Network Theory and Organology. Dournal of the American Musical Instrument Society 44: 41511.

Bauchspies, Wenda K. 2009. Botentials, Actuals and Residues: Entanglements of Culture and Subjectivity. Subjectivity 28 (1): 229245.

Bernstein, Leonard. . 1976. The Unanswered Question: Six Talks at Harvard. Cambridge, MA: Harvard University Press.

Berry, David Carson. . 2006. Journal of Music Theory under Allen ForteElEditorship. Dournal of Music Theory 50 (1): 723.

Born, Georgina. , and Andrew. Barry . 2018. Music, Mediation Theories and Actor-Network Theory. Contemporary Music Review 37 (56): 443487.

Buchanan, Ian. . 2015. Assemblage Theory and Its Discontents. Deleuze Studies 9 (3): 382392.

Buonamano, Roberto. . 2014. The Legal Subject in Althusser巨Political Theory. Waw and

Critique 25 (3): 231248.

Butler, Judith. . 1990. Gender Trouble: Feminism and the Subversion of Identity. New York:

Routledge.

Callon, Michel. . 1986. Whents pour une sociologie de la traduction: La domestication des coquilles Saint-Jacques et des marins-pCheurs dans la baie de Saint-Brieuc. [Anne sociologique 36: 169208.106

Callon, Michel. . 1990. Techno-Economic Networks and Irreversibility. [\$ociological Review 38 (1_suppl): 13261.

Centre National dArt et de Culture Georges Pompidou . 1975. Rapport dactivit[1975. Paris:

Centre National dबrt et de Culture Georges Pompidou.

Chevalier, Jean-Claude. , and Pierre. Encrev $\square$ 2006. Combats pour la linguistique, de Martinet $\square$ Kristeva: Essai de dramaturgie pistmologique. Lyon: ENS ditions.

Chomsky, Noam. . 1964. Aspects of a Theory of Syntax. Cambridge, MA: MIT Press.

Chomsky, Noam. . 1969. American Power and the New Mandarins: Historical and Political Essays. New York: Pantheon Books.

Clarke, Eric. . 1988. Generative Principles in Music Performance. Th Generative Processes in Music: The Psychology of Performance, Improvisation and Composition, edited by John.

Sloboda , 126. Oxford: Clarendon Press.

Collin, Finn. . 2011. Science Studies as Naturalized Philosophy. Cham: Springer.

Crary, Jonathan. . 1990. Techniques of the Observer: On Vision and Modernity in the Nineteenth Century. New York: Zone.

Cumming, Naomi. . 2000. The Sonic Self: Musical Subjectivity and Signification. Bloomington, IN: Indiana University Press. 
Daston, Lorraine. , and Peter. Galison . 2007. Objectivity. New York: Zone.

Deleuze, Gilles. . 2004. Bow Do We Recognize Structuralism? पh Desert Islands and Other

Texts, 1953[1974, edited by David. Lapoujade, 170I92. New York: Semiotexte.

Deleuze, Gilles. . 2006. Foucault. Translated by Sen Hand . London: Continuum.

Deleuze, Gilles. , and Flix. Guattari . 1987. A Thousand Plateaus: Capitalism and

Schizophrenia. Translated by Brian. Massumi . Minneapolis, MN: University of Minnesota Press. Deleuze, Gilles. , and Fix. Guattari . 1994. What Is Philosophy? Translated by Hugh. Tomlinson and Graham. Burchell . New York: Columbia University Press.

DeNora, Tia. . 2000. Music in Everyday Life. Cambridge: Cambridge University Press.

Despret, Vinciane. . 2008. The Becomings of Subjectivity in Animal Worlds. Subjectivity 23 (1): $123 \mathbb{1 1 3 9 .}$

Dominicy, M. 2003. Dicolas Ruwet (19332001). Travaux de linguistique 46: $133 \llbracket 43$.

Dosse, Franסis. . 1997. History of Structuralism, vol. 2, The Sign Sets, 1967Present.

Minneapolis, MN: University of Minnesota Press.

Eco, Umberto. . 2001. Experiences in Translation. Translated by Alastair. McEwen . Toronto, ON: University of Toronto Press.

Fodor, Jerry A. 1983. The Modularity of Mind. Cambridge, MA: MIT Press.

Forte, Allen. . 1967. Music and Computing: The Present Situation. TAFIPS Conference

Proceedings $\mathbb{1 9 6 7}$ Fall Joint Computer Conference 2 (1): 32729.

Geroulanos, Stefanos. . 2017. Transparency in Postwar France: A Critical History of the Present. Stanford, CA: Stanford University Press.

Gomart, Emilie. , and Antoine. Hennion . 1999. A Sociology of Attachment: Music Amateurs, Drug Users. \$Sociological Review 47 (51): 220247.

Greimas, Algirdas Julien. . 1983. Structural Semantics: An Attempt at a Method. Translated by

Danile. McDowell, Ronald. Schleifer, and Alan. Veile . Lincoln, NE: University of Nebraska

Press.

Haraway, Donna J. 1997.

Modest_witness@second_millennium.femaleman@meets_oncomouse: Feminism and Technoscience. New York: Routledge.

Haraway, Donna J. . 2016. Staying with the Trouble: Making Kin in the Chthulucene. Durham, NC: Duke University Press.107

Hennion, Antoine. . 2015. The Passion for Music: A Sociology of Mediation. Translated by Margaret. Rigaud and Peter. Collier . Farnham: Ashgate.

Holtzman, S.R. 1981. Using Generative Grammars for Music Composition. Computer Music Journal 5 (1): 5164.

Hooper, Giles. . 2013. A Sign of the Times: Semiotics in Anglo-American Musicology. $\square$ Twentieth-Century Music 9 (12): 161 IIT6.

Kassler, Michael. . 1967. A Trinity of Essays. PhD Thesis. Princeton University.

Keiler, A. 1978a. Bernsteins The Unanswered Question[and the Problem of Musical

Competence.Musical Quarterly 64 (2): 195R22.

Keiler, A. . 1978b. The Empiricist Illusion: NarmourBBBeyond Schenkerism. Perspectives of New Music 17 (1): 161 प195.

Knorr Cetina, Karin. . 2001. Objectual Practice. In The Practice Turn in Contemporary Theory, edited by Theodore R. Schatzki , Karin Knorr. Cetina, and Eike. von Savigny , 175ா88. London: Routledge.

Kristeva, Julia. . 1974. La rVblution du langage potique. Paris: Seuil.

Kristeva, Julia. . 1986. The System and the Speaking Subject. Th The Kristeva Reader, edited by Toril. Moi , 2433. Oxford: Wiley-Blackwell.

Lacan, Jacques. . 1977. The Four Fundamental Concepts of Psychoanalysis. Translated by Alan. Sheridan . Harmondsworth: Penguin.

Laske, Otto E. 1972. On Musical Strategies with a View to a Generative Theory of Music. $\square$ Interface 1 (2): $111 \mathbb{1 1 2 5}$.

Laske, Otto E. . 1973. W Search of a Generative Grammar of Music. Perspectives of New Music $12(1 D): 351378$.

Latour, Bruno. . 1992. One More Turn after the Social Turn: Easing Science Studies into the Non-Modern World. In The Social Dimensions of Science, edited by Ernan. McMullin , 272 292.

Notre Dame: Notre Dame University Press.

Latour, Bruno. . 1993. We Have Never Been Modern. Translated by Catherine. Porter .

Cambridge, MA: Harvard University Press.

Latour, Bruno. . 1994. On Technical Mediation: Philosophy, Sociology, Genealogy.Common Knowledge 3 (2): 2964.

Latour, Bruno. . 2004a. Why Has Critique Run Out of Steam? From Matters of Fact to Matters of Concern. Critical Inquiry 30 (2): 225248. 
Latour, Bruno. . 2004b. Bow to Talk about the Body? The Normative Dimension of Science Studies. Body \& Society 10 (2B): 205 R29.

Latour, Bruno. . 2005. Reassembling the Social: An Introduction to Actor-Network Theory.

Oxford: Oxford University Press.

Latour, Bruno. . 2013. An Inquiry into Modes of Existence. Translated by Catherine. Porter . Cambridge, MA: Harvard University Press.

Law, John. . 2008. Actor-Network Theory and Material Semiotics. In The New Blackwell Companion to Social Theory, edited by Brian S. Turner, 141ㅍ⒏ Oxford: Wiley-Blackwell. Lenoir, Timothy. . 1994. Was that Last Turn a Right Turn? The Semiotic Turn and A. J. Greimas. Configurations 2: $119 \mathbb{1 3} 6$.

Lerdahl, Fred. , and Ray S. Jackendoff . 1983. A Generative Theory of Tonal Music. Cambridge, MA: MIT Press.

Liu, Lydia H. 2010. The Cybernetic Unconscious: Rethinking Lacan, Poe, and French Theory. $\square$ Critical Inquiry 36 (2): 288320.

Lorenzini, Daniele. and Tazzioli, Mark. . 2020. Qritique without Ontology: Genealogy, Collective Subjects and the Deadlocks of Evidence. Radical Philosophy Spring 2020 (2.07): 2739.108 Malm, Andreas. . 2018. The Progress of this Storm: Nature and Society in a Warming World. London: Verso.

Maniglier, Patrice. . 2012. Acting Out the Structure.Wh Concept and Form, vol. 2: Essays and Interviews on the Cahiers pour lanalyse, edited by Peter. Hallward and Knox. Peden , 2546. London: Verso.

Massumi, Brian. . 1992. A UserEGuide to Capitalism and Schizophrenia. Cambridge, MA: MIT Press.

Mehr, Samuel A. , et al. 2019. Universality and Diversity in Human Song. [Science 366 (970): 1 IIT.

Mercier, Lucie Kim Chi. . 2019. Michel Serresחeibnizian Structuralism. [Angelaki: Journal of the Theoretical Humanities 24 (6): 3211.

Miller, Jacques-Alain. . 1968. Action de la structure.Cahiers pour lanalyse 9: 930․

Milner, Jean-Claude. . 1978. Lamour de la langue. Paris: Seuil.

Milner, Jean-Claude. . 2002. Le pఢiple structural: Figures et paradigme. Paris: Seuil.

Milner, Jean-Claude. . 2013. Eorme et structure ou le conte des faux jumeaux. Mes Temps Modernes 5 (676): $120 \mathbb{1 4 3}$.

Milner, Jean-Claude. , and Knox. Peden . 2012. The Force of Minimalism. Th Concept and Form, vol. 2, Essays and Interviews on the Cahiers pour lanalyse, edited by Peter. Hallward and Knox. Peden , 2292444. London: Verso.

Mol, Annemarie. . 2002. The Body Multiple: Ontology in Medical Practice. Durham, NC: Duke University Press.

Narmour, Eugene. . 1977. Beyond Schenkerism. Chicago, IL: University of Chicago Press. Nattiez, Jean-Jacques. . 1975. De la smiologie tha smantique musicale.Musique en jeu 17: 39 Newmeyer, Frederick J. 1996. Generative Linguistics: An Historical Perspective. New York: Routledge.

Noys, Benjamin. . 2010. The Persistence of the Negative. Edinburgh: Edinburgh University Press.

Pearce, Marcus. , and Geraint A. Wiggins . 2002. Aspects of a Cognitive Theory of Creativity in Musical Composition. 2nd International Workshop on Creative Systems: European Conference on Artificial Intelligence. Lyon.

Piekut, Benjamin. . 2012. Sounds్Modest Witness: Notes on Cage and Modernism. $\square$ Contemporary Music Review 31 (1): 3ா8.

Popper, Karl R. 1963. Conjectures and Refutations: The Growth of Scientific Knowledge. London: Routledge.

Puig de la Bellacasa, Maria. . 2011. Matters of Care in Technoscience: Assembling Neglected Things. [\$ocial Studies of Science 41 (1): 85ए06.

Putnam, Hilary. . 1967. The [nnateness Hypothesisand Explanatory Models in Linguistics. $\square$ Synthese 17: 1220.

Putnam, Hilary. . 1988. Representation and Reality. Cambridge, MA: MIT Press.

Roads, Curtis. , and Paul. Wieneke . 1979. Grammars as Representations for Music. Computer Music Journal 3 (1): 4855.

Roberts, Celia. . 2002. A Matter of Embodied Fact: Sex Hormones and the History of Bodies. $\square$ Feminist Theory 3 (1): 7266.

Rohrmeier, Martin. . 2011. Towards a Generative Syntax of Tonal Harmony. Dournal of Mathematics and Music 5 (1): 3553.

Ruwet, Nicolas. . 1959. Contradictions du langage stiel. Revevue Belge de Musicologie/Belgisch Tijdschrift voor Muziekwetenschap 13 (1/4): 8397.109 
Ruwet, Nicolas. . 1966. Musicologie et linguistique. UNESCO/SS/41/3.244.1/h/24.

Ruwet, Nicolas. . 1967. Introduction Tha grammaire gnrative. Paris: Plon.

Ruwet, Nicolas. . 1975. ThWrie et methodes dans les tudes musicales. Musique en jeu 17:

1136.

Schaeffer, Pierre. . 2017. Treatise on Musical Objects: An Essay across Disciplines. Translated by Christine. North and John. Dack . Berkeley, CA: University of California Press.

Schmidgen, Henning. . 2015. Bruno Latour in Pieces: An Intellectual Biography. New York: Fordham University Press.

Schrift, Alan D. 2004. ES There Such a Thing as Erench Philosophy? Or Why Do We Read the French So Badly? Пh After the Deluge: New Perspectives on the Intellectual and Cultural History of Postwar France, edited by Julian. Bourg , 2147. Oxford: Lexington Books.

Schuijer, Michael. . 2008. Analyzing Atonal Music: Pitch-Class Set Theory and Its Contexts. Rochester, NY: University of Rochester Press.

Serres, Michel. . 1969. HermsI : La communication. Paris: Les ditions de minuit.

Serres, Michel. . 1974. HermsIII : La traduction. Paris: Les ditions de minuit.

Serres, Michel. . 2013. Petite Poucette. Paris: Le Pommier.

Serres, Michel. , and Bruno. Latour . 1994. Claircissements. Paris: Flammarion.

Smoliar, Stephen W. 1976. Music Programs: An Approach to Music Theory through

Computational Linguistics. Journal of Music Theory 20 (1): 105『31.

Sotiris, Panagiotis. . 2014. Bow to Make Lasting Encounters: Althusser and Political

Subjectivity. Rethinking Marxism 26 (3): 398 任3.

Starr, Peter. . 1995. Logics of Failed Revolt: French Theory after May 68. Stanford, CA:

Stanford University Press.

Steedman, Mark J. 1984. \& Generative Grammar for Jazz Chord Sequences. Music Perception 2 (1): $52 \pi 7$.

Strathern, Marilyn. . 1996. Dutting the Network. Dournal of the Royal Anthropological Institute 2 (3): 517535.

Strathern, Marilyn. . 2005. Partial Connections. Updated ed. Lanham, MD: Rowman \& Littlefield. Sturman, Susan. . 2006. On Black-Boxing Gender: Some Social Questions for Bruno Latour. $\square$ Social Epistemology 20 (2): $181 \mathbb{1 1 8 4 .}$

Taylor, Timothy D. 2001. Strange Sounds: Music, Technology and Culture. New York:

Routledge.

Valiquet, Patrick. . 2017. Bearing the Music of Others: Pierre SchaefferฐHumanist Interdiscipline. Music \& Letters 98 (2): 255280.

Van de Walle, Jggen. . 2008. Boman Jakobson, Cybernetics and Information Theory: A Critical Assessment. Folia Linguistica Historica 29 (12): 87프.

Winograd, Terry. . 1968. Inguistics and the Computer Analysis of Tonal Harmony.Dournal of Music Theory 12 (1): 249.

Zahavi, Dan. . 2003. Husserls Phenomenology. Stanford, CA: Stanford University Press.110

\section{Sonic imaginaries}

Bailey, Derek. . 1993. Improvisation: Its Nature and Practice in Music. New ed. New York: Da Capo.

Bates, Eliot. . 2012. The Social Life of Musical Instruments. ㅍthnomusicology 56 (3): 363395.

Bayle, Franסis. , and Hugh. Davies . 1966. Letter and Questionnaire to Studio Managers, undated c. 1966, MS Mus. 1803, Box 2, Folder 3/2/5, Hugh Seymour Davies papers, British Library, London.

Beckert, Jens. . 2016. Imagined Futures: Fictional Expectations and Capitalist Dynamics. Cambridge, MA: Harvard University Press.

Bijsterveld, Karin. . 2019. Sonic Skills: Listening for Knowledge in Science, Medicine and Engineering, 1920sPresent. London: Springer.

Born, Georgina. and Andrew. Barry . 2018. Music, Mediation Theories and Actor-Network Theory. Contemporary Music Review 37 (56): 443487.

Bull, Michael. . 2020. Sirens. London: Bloomsbury.

Campbell, Philip. . 1986. The Music of Digital Computers. WNature 324 (December): 523528.

Castoriadis, Cornelius. . 1987. Imaginary Institution of Society: Creativity and Autonomy in the Social-Historical World. Cambridge, MA: MIT Press.

Chadabe, Joel. . 1997. Electric Sound: The Past and Promise of Electronic Music. Upper

Saddle River, NJ: Prentice Hall. 
Clark, Colin. , and Trevor. Pinch . 1988. Micro-Sociology and Micro-Economics: Selling by Social Control. Th Actions and Structure: Research Methods and Social Theory, edited by Nigel. Fielding , 119प41. Beverly Hills, CA: SAGE.

Clark, Colin. , and Trevor. Pinch . 2014. The Hard Sell: The Language and Lessons of Streetwise Marketing. London: Sociografica.

Collins, Nicolas. . 2009. Handmade Electronic Music: The Art of Hardware Hacking. 2nd ed. New York: Routledge.

Darr, Asaf. , and Trevor. Pinch . 2013. Performing Sales: Material Scripts and the Social Organization of Obligation. Organization Studies 34 (11): 1601 11621.

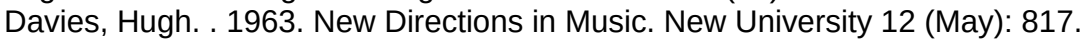

Davies, Hugh. . 1966. Letter to Allen Percival, May 2, 1966, MS Mus. 1803, Box 7, Folder 13, Hugh Seymour Davies papers, British Library, London.

Davies, Hugh. . 1967. Letter to Jaap Spek, undated c. early 1967, MS Mus. 1803, Box 7, Folder 32, Hugh Seymour Davies papers, British Library, London.

Davies, Hugh. . 1968a. Rpertoire International Des Musiques lectroacoustiques / International Electronic Music Catalog. Paris: Groupe de Recherches Musicales de IORTF; Trumansburg, NY: Independent Electronic Music Center, Inc.; Cambridge, MA: MIT Press.

146 Davies, Hugh. . 1968b. Working with Stockhausen.Composer 27: 8Th.

Davies, Hugh. . 1968c. Electronic Workshop.The Musical Times 109 (1501): 235.

https://doi.org/10.2307/953494.

Davies, Hugh. . 1970. Problems of Live Electronic Music, Thandwritten notes, undated c. 1970,

MS Mus. 1803, Box 2, Folder 8/12, Hugh Seymour Davies papers, British Library, London.

Davies, Hugh. . 1971. Quintet. \$ource: Music of the Avant-Garde 10: 8487.

Davies, Hugh. . 1977. Electronic Music Studios in Britainfl Goldsmiths College, University of London. Contact 15 (Winter 1976/77): 29311.

Davies, Hugh. . 1981. Making and Performing Simple Electroacoustic Instruments. In Electronic Music for Schools, edited by Richard. Orton , 152174. Cambridge: Cambridge University Press. Davies, Hugh. . 1992. Dew Musical Instruments in the Computer Age: Amplified Performance Systems and Related Examples of Low-Level Technology. In Companion to Contemporary Musical Thought, edited by John. Paynter 1:500513. London: Routledge.

Davies, Hugh. . 1997. [ivented Instruments and Improvisation. CAvant: Jazz, Improvised and Contemporary Classical Music, Spring 1997: 12115.

Davies, Hugh. . 2001. Gentle Fire: An Early Approach to Live Electronic Music. ஐeonardo Music Journal 11: 5360 .

Davies, Hugh. . 2002a. Audio Art: Notes towards a Definition(1992). In Sounds Heard: A Potpourri of Environmental Projects and Documentation, Projects with Children, Simple Musical Instruments, Sound Installations, Verbal Scores, and Historical Perspectives, 33. Chelmsford: Soundworld.

Davies, Hugh. . 2002b. Euture Developments in Electronic Music(11972). In Sounds Heard: A Potpourri of Environmental Projects and Documentation, Projects with Children, Simple Musical Instruments, Sound Installations, Verbal Scores, and Historical Perspectives, 25. Chelmsford: Soundworld.

Davies, Hugh. . 2002c. JlgamareeQ(1977). In Sounds Heard: A Potpourri of Environmental Projects and Documentation, Projects with Children, Simple Musical Instruments, Sound Installations, Verbal Scores, and Historical Perspectives, 77. Chelmsford: Soundworld. Davies, Hugh. . 2002d. Dew Musical Instruments(11989). In Sounds Heard: A Potpourri of Environmental Projects and Documentation, Projects with Children, Simple Musical Instruments, Sound Installations, Verbal Scores, and Historical Perspectives, 31BD. Chelmsford: Soundworld.

Davies, Hugh. . 2002e. Boint of View (Manifesto)Q1977). In Sounds Heard: A Potpourri of Environmental Projects and Documentation, Projects with Children, Simple Musical Instruments, Sound Installations, Verbal Scores, and Historical Perspectives, 18. Chelmsford: Soundworld.

Davies, Hugh. . 2002f. The Aims of My Musical Projects for Children(11977/1993). In Sounds Heard: A Potpourri of Environmental Projects and Documentation, Projects with Children, Simple Musical Instruments, Sound Installations, Verbal Scores, and Historical Perspectives, 96. Chelmsford: Soundworld.

Davies, Hugh. . 2002g. The Musical Potential of Found Objects in New Instruments Invented by Young PeopleQ(1994). In Sounds Heard: A Potpourri of Environmental Projects and Documentation, Projects with Children, Simple Musical Instruments, Sound Installations, Verbal Scores, and Historical Perspectives, 9095. Chelmsford: Soundworld.

147 Davies, Hugh. . 2002h. The Role of the ArtistL(1976). In Sounds Heard: A Potpourri of Environmental Projects and Documentation, Projects with Children, Simple Musical Instruments, Sound Installations, Verbal Scores, and Historical Perspectives, 17. Chelmsford: 
Soundworld.

Douglas, Susan J. 2004. Listening In: Radio and the American Imagination. Minneapolis, MN: University of Minnesota Press.

Gilby, Ian. . 1987. Electronic Music Studio: Goldsmiths College, University of London. \$ound on Sound, February 1987.

Grimshaw-Aagaard, Mark. , Mads. Walther-Hansen, and Martin. Knakkergaard . 2019. The Oxford Handbook of Sound and Imagination. Oxford: Oxford University Press.

Hennion, Antoine. . 2015. The Passion for Music: A Sociology of Mediation. Farnham: Ashgate. Holland, Simon. , Tom. Mudd, Katie. Wilkie-McKenna, Andrew. McPherson, and Marcelo. Wanderley, eds. 2019. New Directions in Music and Human-Computer Interaction. New York: Springer.

Holland, Simon. , Tom. Mudd, Katie. Wilkie-McKenna, Andrew. McPherson, and Marcelo. Wanderley . 2016. Electronic and Experimental Music. 5th ed. New York: Routledge. Holmes, Thom. . 2016. Electronic and Experimental Music: Pioneers in Technology and Composition. New York: Routledge.

Hugill, Andrew. . 2007. The Origins of Electronic Music. Wh The Cambridge Companion to Electronic Music, edited by Nick. Collins and Julio. dEscrivan , 7飞ß. Cambridge: Cambridge University Press.

Ingold, Tim. . 2013. Making: Anthropology, Archaeology, Art and Architecture. London: Routledge.

Jasanoff, Sheila. , and Sang-Hyun. Kim . 2009. Containing the Atom: Sociotechnical Imaginaries and Nuclear Power in the United States and South Korea. MMinerva 47 (2): 119『46. doi: 10.1007/s11024-009-9124-4.

Jasanoff, Sheila. , and Sang-Hyun. Kim . 2013. Sociotechnical Imaginaries and National Energy Policies. [Science as Culture 22 (2): 189[196. doi: 10.1080/09505431.2013.786990.

Jasanoff, Sheila. , and Sang-Hyun. Kim . 2015. Dreamscapes of Modernity: Sociotechnical Imaginaries and the Fabrication of Power. Chicago, IL: University of Chicago Press.

Lesaffre, Micheline. , and Greg. Jacobs, eds. 2013. Institute for Psychoacoustics and Electronic Music: 50 Years of Electronic and Electroacoustic Music at the Ghent University. Brussels:

Metaphon.

Meintjes, Louise. . 2003. Sound of Africa! Making Music Zulu in a South African Studio.

Durham, NC: Duke University Press.

Meloni, Maurizio. , and Giuseppe. Testa . 2014. Scrutinizing the Epigenetics Revolution. $\square$ BioSocieties 9 (4): 431456.

Mooney, James. . 2015a. Bugh DaviesEEElectronic Music Documentation 1961ㅍ68. Drganised Sound 20 (1): 111II21. doi: 10.1017/S1355771814000521.

Mooney, James. . 2015b. Bugh DaviesB]Electroacoustic Musical Instruments and Their Relation to Present-Day Live Coding Practice: Some Historic Precedents and Similarities. In

Proceedings of the First International Conference on Live Coding (pp. 5362). Leeds, UK: ICSRiM, University of Leeds. Zenodo. doi: 10.5281/zenodo.19319.

Mooney, James. . 2016a. Bugh Davies, Galactic Interfaces, Mlobile with Differences, [and

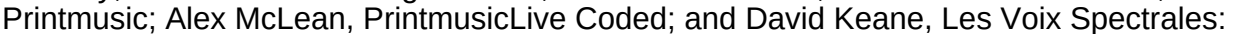
Performances by Grey Area and Alex McLean, with Pre-Concert Lecture by James Mooney. $\square$ Video recordings. University of Leeds. doi: 10.5518/57.

Mooney, James. . 2016b. Bugh Davies, Quintetand Music for a Single Spring,_Stockhausen, Derbindung and [itensitatfrom Aus Den Sieben Tagen $\square$ Christian Wolff, Edges, Green, Deither the Time nor the Energy $\square$ Performances by Grey Area, with 148Pre-Concert Lecture by James Mooney. Video recordings. University of Leeds. doi: 10.5518/38.

Mooney, James. . 2016c. Dechnology, Process and Musical Personality in the Music of Stockhausen, Hugh Davies and Gentle Fire. In The Musical Legacy of Karlheinz Stockhausen: Looking Back and Forward, edited by Morag J. Grant and Imke. Misch , 102T15. Hofheim: Wolke.

Mooney, James. . 2017. The Hugh Davies Collection: Live Electronic Music and Self-Built Electro-Acoustic Musical Instruments, 1967 11975. Science Museum Group Journal 7 (April). doi: 10.15180/170705.

Mooney, James. , Owen. Green, and Sean. Williams . Forthcoming. [nstrumental, Hermeneutic, and Ontological Indeterminacy in Hugh DaviesEL Live Electronic Music. $\square$

Morus, Iwan. . 2015. Do Mere Dream: Material Culture and Electrical Imagination in Late Victorian Britain.Centaurus 57 (3): 173प91. doi: 10.1111/1600-0498.12093.

Music in Our Time. 1973. BBC Radio 3, July 3, 1973, 3:55pm. Interview with Gentle Fire (interviewer: Stephen Plaistow), audio recording, C1193/35, Hugh Davies collection, British Library, London.

Novati, Maria Maddalena. , and John. Dack , eds. 2012. The Studio Di Fonologia: A Musical Journey 1954983, Update 2008R012. Milan: Ricordi. 
Nye, David E. 1996. American Technological Sublime. Cambridge, MA: MIT Press.

Park Lane Group and Society for the Promotion of New Music . 1968. Electronic Music at the

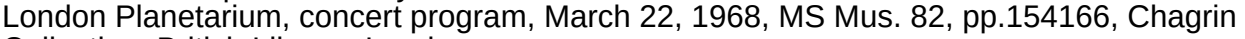
Collection, British Library, London.

Partch, Harry. . 1948 (1974). Genesis of a Music: An Account of a Creative Work, Its Roots and Its Fulfillments. New York: Da Capo Press.

Patteson, Thomas W. 2016. Instruments for New Music: Sound, Technology, and Modernism.

Oakland, CA: University of California Press.

Piekut, Benjamin. . 2011. Experimentalism Otherwise: The New York Avant-Garde and Its Limits. Berkeley, CA: University of California Press.

Pinch, Trevor. . 2005. Giving Birth to New Users: How the Minimoog Was Sold to Rock and Roll. Wh How Users Matter: The Co-Construction of Users and Technology, edited by Nellie. Oudshoorn and Trevor. Pinch . New ed. Cambridge, MA: MIT Press, 247070.

Pinch, Trevor. , and Karin. Bijsterveld, eds. 2012. The Oxford Handbook of Sound Studies. New York: Oxford University Press.

Pinch, Trevor. , and Colin. Clark . 1986. The Hard Sell: Batter Merchantingland the Strategic (Re)Production and Local Management of Economic Reasoning in the Sales Routines of Market Pitchers.\$ociology 20 (2): 169 प191.

Pinch, Trevor. , and Frank. Trocco . 2002. Analog Days: The Invention and Impact of the Moog Synthesizer. New ed. Cambridge, MA: Harvard University Press.

Rice, Tom. . 2013. Hearing and the Hospital: Sound, Listening, Knowledge and Experience.

Canon Pyon, Hereford: Sean Kingston Publishing.

Risset, Jean-Claude. . 1991. Some Comments about Future Music Machines. Computer Music Journal 15 (4): 3236. doi: 10.2307/3681069.

Roberts, David. . 1977. Bugh Davies: Instrument Maker.Contact 17: 8[3.

Sanden, Paul. . 2013. Liveness in Modern Music: Musicians, Technology, and the Perception of Performance. New York: Routledge.

Sovacool, Benjamin K. 2011. Contesting the Future of Nuclear Power: A Critical Global Assessment of Atomic Energy. Hackensack, NJ: World Scientific.

Spek, Jaap. . 1967a. Letter to Hugh Davies, January 2, 1967, MS Mus. 1803, Box 7, Folder 32, Hugh Seymour Davies papers, British Library, London.

149 Spek, Jaap. . 1967b. Letter to Hugh Davies, March 30, 1967, MS Mus. 1803, Box 7, Folder 32, Hugh Seymour Davies papers, British Library, London.

Spek, Jaap. . 1967c. Letter to Hugh Davies, July 11, 1967, MS Mus. 1803, Box 7, Folder 32, Hugh Seymour Davies papers, British Library, London.

Sterne, Jonathan. , ed. 2012. The Sound Studies Reader. London: Routledge.

Stubbs, David. . 2018. Mars by 1980: The Story of Electronic Music. London: Faber \& Faber.

Tazelaar, Kees. . 2013. On the Threshold of Beauty: Philips and the Origins of Electronic Music in the Netherlands, 1925 1965 . Rotterdam: NAI.

ThDerge, Paul. . 1997. Any Sound You Can Imagine: Making Music/Consuming Technology. Hanover, NH: Wesleyan University Press.

Toop, David. , ed. 1974. New/Rediscovered Musical Instruments. London: Quartz/Mirliton. Tovar-Restrepo, Marcela. . 2012. Castoriadis, Foucault, and Autonomy: New Approaches to Subjectivity, Society, and Social Change. Bloomsbury Studies in Continental Philosophy. New York: Continuum.

Turner, Fred. . 2010. From Counterculture to Cyberculture: Stewart Brand, the Whole Earth Network, and the Rise of Digital Utopianism. Chicago, IL: University of Chicago Press.

Waksman, Steve. . 1999. Instruments of Desire: The Electric Guitar and the Shaping of Musical Experience. Cambridge, MA: Harvard University Press.

Weidenaar, Reynold. . 1995. Magic Music from the Telharmonium. Metuchen, NJ: Scarecrow Press.

Weium, Frode. , and Tim. Boon , eds. 2013. Material Culture and Electronic Sound. Artefacts: Studies in the History of Science and Technology, v. 8. Washington, DC: Smithsonian Institution Scholarly Press; Lanham, MD: Rowman \& Littlefield.

Zunz, Olivier. . 1990. Making America Corporate, 1870I920. Chicago, IL: University of Chicago Press. 


\section{Following the instruments}

Akrich, Madeleine. . 1992. The De-Scription of Technical Objects. Шh Shaping

Technology/Building Society: Studies in Sociotechnical Change, edited by Wiebe E. Bijker and John. Law, 205R24. Cambridge, MA: MIT Press.

Bernstein, David W. , and Maggi. Payne . 2008. Don Buchla. In The San Francisco Tape Music Center: 1960s Counterculture and the Avant-Garde, edited by David W. Bernstein , $163 \mathbb{W 7} 7$.

Berkeley, CA: University of California Press.

Bijker, Wiebe E. , Thomas Parke. Hughes, and Trevor J. Pinch , eds. 1987. The Social Construction of Technological Systems: New Directions in the Sociology and History of Technology. Cambridge, MA: MIT Press.

Bijker, Wiebe E. , and Trevor J. Pinch . 2012. Preface to the Anniversary Edition of The Social Construction of Technological Systems: New Directions in the Sociology and History of Technology, edited by Wiebe E. Bijker, Thomas Parke. Hughes, and Trevor J. Pinch, xi区xxiv. Cambridge, MA: MIT Press.

Bright, Spencer. . 2000. Peter Gabriel: An Authorised Biography. London: Pan.

Briscoe, Desmond. , and Roy. Curtis-Bramwell . 1983. The BBC Radiophonic Workshop: The First 25 Years. London: BBC.

Burgess, Richard J. 2011. Interview by the author. Minidisc Recording. Skype. May 21, 2011.

Burgess, Richard J. . 2014. The History of Music Production. New York: Oxford University

Press.

Buskin, Richard. . 2008. Classic Tracks: Afrika Bambaataa \& The Soulsonic Force Planet Rock. $\square$ Sound on Sound, November 2008, 7884.

Crombie, Dave. . 1979. Man Bytes Dog. \$ound International, December 1979, 7.

Dawson, Giles. . 1983. Mlachines Alive with the Sound of Music. $\mathbb{N}$ ew Scientist, August 1983, $333 B 35$.

Denyer, Ralph. . 1980. Eberhard Schoener.\$Sound International, May 1980, $14 \mathbb{I 6 .}$

Diliberto, John. . 1985. Kate Bush: From Piano to Fairlight with BritainsE Exotic Chanteuse. $\square$ Keyboard, July 1985, 5673.

Doerschuk, Bob. . 1983. The Great Synthesizer Debate.Keyboard, December 1983, 3862.

Fabbri, Franco. . 2010. 四 Like My Record to Sound Like this Peter Gabriel and Audio

Technology. Wh Peter Gabriel: From Genesis to Growing Up, edited by Michael. Drewett , Sarah. Hill , and Kimi. KFki , 173प82. Farnham: Ashgate.

Fairlight . 1980. Turn this Page and the Future of Music Is Passed[\$ound International,

September 1980, 5.

Fairlight . 1983. Fairlight Computer Musical Instrument. Sydney, NSW: Fairlight Instruments.

Fairlight . 2011. Fairlight CMI-30A: The Legend Returns. Mona Vale: Fairlight Instruments.

Fink, Robert. . 2005. The Story of ORCH5, or, The Classical Ghost in the Hip-Hop Machine. $\square$

Popular Music 24 (3): 339356.

Gibson, James J. 1979. The Ecological Approach to Visual Perception. Boston, MA: Houghton Mifflin.

Harkins, Paul. . 2019. Digital Sampling: The Design and Use of Music Technologies. London: Routledge.

Hutchby, Ian. . 2001. Technologies, Texts, and Affordances. Sociology 35 (2): 441456.

Jeczalik, J.J. 2011. Interview by the author. Minidisc Recording. Skype. June 4, 2011.

Wate Bush.1982. Electronics \& Music Maker, October 1982, 4447.

Kelly, Michael. . 2015. Interview by the author. Email. September 21, 2015.

169 Latour, Bruno. . 1992. Where Are the Missing Masses? The Sociology of a Few Mundane Objects. Wh Shaping Technology/Building Society: Studies in Sociotechnical Change, edited by Wiebe E. Bijker and John. Law , 225258. Cambridge, MA: MIT Press.

Levine, Steve. , and J. William. Mauchly . 1980. The Fairlight Computer Musical Instrument. Пh Proceedings of the 1980 International Computer Music Conference, Queens College of the City, University of New York, 565573.

Niebur, Louis. . 2010. Special Sound: The Creation and Legacy of the BBC Radiophonic Workshop. New York: Oxford University Press.

Oudshoorn, Nelly. , and Trevor J. Pinch , eds. 2003. eds. How Users Matter: The CoConstruction of Users and Technology. Cambridge, MA: MIT Press.

Pinch, Trevor J. 2003. Giving Birth to New Users: How the Minimoog Was Sold to Rock and Roll. Th How Users Matter: The Co-Construction of Users and Technology, edited by Nelly. Oudshoorn and Trevor J. Pinch. , 247270. Cambridge, MA: MIT Press.

Pinch, Trevor J. , and Wiebe E. Bijker . 1984. The Social Construction of Facts and Artefacts: Or How the Sociology of Science and the Sociology of Technology Might Benefit Each Other. Social Studies of Science 14 (3): 399441. 
Pinch, Trevor J. , and Karin. Bijsterveld . 2004. Slound Studies: New Technologies and Music. $\square$ Social Studies of Science 34 (5): 635648.

Pinch, Trevor J. , and Frank. Trocco . 2002. Analog Days: The Invention and Impact of the Moog Synthesizer. Cambridge, MA: Harvard University Press.

Rodgers, Tara. . 2015. Tinkering with Cultural Memory: Gender and the Politics of Synthesizer Historiography. שFeminist Media Histories 1 (4): 5BD.

Rossi Rognoni, Gabriele. . 2018. Organology and the Others: A Political Perspective. Dournal of the American Musical Instrument Society 44: 7 II7.

Sterne, Jonathan. . 2003. The Audible Past: Cultural Origins of Sound Reproduction. Durham, NC: Duke University Press.

Stewart, Andy. . 2005. The Name Behind the Name: Bruce JacksonApogee, Jands, Lake Technology. [Audio Technology, May 2005, 6570.

Street, Rita. . 2000. Eairlight: A 25-Year Long Fairytale.FAudio Media, November 8, 2000. Thberge, Paul. . 1997. Any Sound You Can Imagine: Making Music / Consuming Technology. Middletown, CT: Wesleyan University Press.

Thomson, Graeme. . 2010. Under the Ivy: The Life and Music of Kate Bush. London: Omnibus Press.

Tingen, Paul. . 1996. Eairlight: The Whole Story. CAudio Media, January 1996, 4855.

Toop, David. . 1999. Exotica: fabricated soundscapes in a real world/David Toop. London:

SerpentsTail.

Toop, David. . 2000. Bip-Hop: Iron Needles of Death and a Piece of Wax. In Modulations: A History of Electronic Music, edited by Peter. Shapiro , 90106. New York: Caipirinha Productions. Tosoni, Simone. , and Trevor. Pinch . 2017. Entanglements: Conversations on the Human Traces of Science, Technology, and Sound. Cambridge, MA: MIT Press.

Tresch, John. , and Emily I. Dolan . 2013. Шoward a New Organology: Instruments of Music and Science.Dsiris 28 (1) 278298.

Vail, Mark. . 2000. Eairlight CMI: Trailblazing Megabuck Sampler.đn Vintage Synthesizers, edited by Mark. Vail , 214ㄲ19. San Francisco, CA: Miller Freeman.

Vogel, Peter. . 2011. Interview by the author. Email. July 4, 2011.

\section{The interface and instrumentality of Eurorack modular synthesis}

Akrich, Madeleine. . 1992. The De-Scription of Technical Objects. Wh Shaping

Technology/Building Society: Studies in Sociotechnical Change, edited by Wiebe E. Bijker and John. Law , 205R24. Cambridge, MA: MIT Press.

Bates, Eliot. . 2012. The Social Life of Musical Instruments. एthnomusicology 56 (3): 363395.

Bates, Eliot. . 2021. Eeeling Analog: Using Modular Synthesisers, Designing Synthesis

Communities. In Shaping Sound and Society: The Cultural Study of Musical Instruments, edited by Steven. Cottrell . New York: Routledge.

Bijsterveld, Karin. , and Marten. Schulp . 2004. Breaking into a World of Perfection: Innovation in Todayฐ Classical Musical Instruments. \$ocial Studies of Science 34 (5): 649674.

Bonanno, Carmine. . 1984. Guitar Controller for a Music Synthesizer. United States patent US 4,630,520A, filed November 8 .

Born, Georgina. , and Kyle. Devine . 2015. Music Technology, Gender, and Class: Digitization, Educational and Social Change in Britain. Twentieth-Century Music 12 (2): 135W72.

Botstein, Sam. . 2014. Tony Rolando (Make Noise).The Distillery. September 24, 2014.

https://www.stitcher.com/podcast/sam-botstein-2/the-distillery/e/36619312.

Bratton, Benjamin H. 2015. The Stack: On Software and Sovereignty. Cambridge, MA: MIT

Press.

BrVg-Hanssen, Ragnhild. , and Anne. Danielsen . 2016. Digital Signatures: The Impact of

Digitization on Popular Music Sound. Cambridge, MA: MIT Press.

Butler, Mark J. 2014. Playing with Something that Runs: Technology, Improvisation, and

Composition in DJ and Laptop Performance. New York: Oxford University Press.

Collins, Nicolas. . 2009. Handmade Electronic Music: The Art of Hardware Hacking. New York:

Routledge.

DErrico, Mike. . 2016. [nterface Aesthetics: Sound, Software, and the Ecology of Digital Audio

Production. $\mathbb{P h D}$ diss., UCLA.

Eshun, Kodwo. . 1998. More Brilliant than the Sun: Adventures in Sonic Fiction. London:

Quartet Books. 
Galloway, Alexander R. 2012. The Interface Effect. Cambridge, MA: Polity Press.

Gaston, Ryan. . 2016. Blays Well with Others: Regarding Modular Synthesizer in Collaborative Performance Practice.EEContact! 17 (4). https://econtact.ca/17_4/gaston_playswell.html.

Ghazala, Reed. . 2005. Circuit-Bending: Build Your Own Alien Instruments. New York: Wiley.

Gibson, J. J. 1979. The Ecological Approach to Visual Perception. Boston, MA: Houghton Mifflin.

Gross, Shad. , Jeffrey. Bardzell , and Shaowen. Bardzell . 2014. Skeu the Evolution:

Skeuomorphs, Style, and the Material of Tangible Interactions. 8th International Conference on Tangible, Embedded and Embodied Interaction. Munich, DE.

187 Hardjowirogo, Sarah-Indriyati. . 2017. mstrumentality: On the Construction of Instrumental Identity. [n Musical Instruments in the 21st Century: Identities, Configurations, Practices, edited by Till. Bovermann , Alberto. de Campo , Hauke. Egermann , Sarah-Indriyati. Hardjowirogo , and Stefan. Weinzierl, 9DK4. Singapore: Springer.

Harkins, Paul. . 2019. Digital Sampling: The Design and Use of Music Technologies. Boca Raton, FL: CRC Press.

Helmreich, Stefan. . 2015. Transduction. In Keywords in Sound, edited by David. Novak and Matt. Sakakeeny , 222R31. Durham, NC: Duke University Press.

Ihde, Don. . 1991. Instrumental Realism: The Interface between Philosophy of Science and Philosophy of Technology. Bloomington, IN: Indiana University Press.

Kheshti, Roshanak. . 2019. Wendy Carlos\$ Switched-On Bach (33 1/3). New York: Bloomsbury. Lanier, Jaron. . 2010. You Are not a Gadget: A Manifesto. New York: Alfred A. Knopf. Latour, Bruno. . 1987. Science in Action: How to Follow Scientists and Engineers Through Society. Cambridge, MA: Harvard University Press.

Lynch, Kevin M. , and Nicholas. Marchuk . 2014. Embedded Computing in C with the PIC32 Microcontroller. Evanston, IL: Northwestern Mechatronics Design Lab.

Magnusson, Thor. . 2019. Sonic Writing: Technologies of Material, Symbolic, and Signal Inscriptions. New York: Bloomsbury Academic.

Meintjes, Louise. . 2003. Sound of Africa!: Making Music Zulu in a South African Studio. Durham, NC: Duke University Press.

Navs . 2016. Blasic Electricity: An Appeal for a Greater Understanding of Rudimentary Modular Functions.EContact! 17 (4). https://econtact.ca/17_4/navs_basicelectricity.html.

Norman, Don. . 2013. The Design of Everyday Things. Rev. ed. New York: Basic Books.

Oudshoorn, Nelly. , and Trevor J. Pinch . 2003. How Users Matter: The Co-Construction of Users and Technologies. Cambridge, MA: MIT Press.

Pinch, Trevor. . 2008. Technology and Institutions: Living in a Material World.Theory and Society 37 (5): 461483.

Pinch, Trevor. . 2016. Bring on Sector Two!-The Sounds of Bent and Broken Circuits. Sound Studies 2 (1): 36511.

Pinch, Trevor. , and Karin. Bijsterveld . 2004. Sound Studies: New Technologies and Music. $\square$ Social Studies of Science 34 (5): 635648.

Pinch, Trevor. , and Frank. Trocco . 2002. Analog Days: The Invention and Impact of the Moog Synthesizer. Cambridge, MA: Harvard University Press.

Pink, Sarah. , Heather. Horst, John. Postill , Larissa. Hjorth, Tania. Lewis, and Jo. Tacchi . 2016. Digital Ethnography Principles and Practice. London: SAGE.

Popp, Constantin. , and R. Soria-Luz . 2015. Developing Mixer-Style Controllers Based on Arduino/Teensy Microcontrollers. In The 12th Sound and Music Computer Conference, Maynooth University, Maynooth, Ireland, 374t1.

Rasmussen, Anne K. 1996. Theory and Practice at the Arabic OrgDigital Technology in Contemporary Arab Music Performance. Popular Music 15 (3): 345365.

Rodgers, Tara. . 2010. Pink Noises: Women on Electronic Music and Sound. Durham, NC:

Duke University Press.

Scott, Richard. . 2016. Black to the Future: On Misunderstanding Modular Synthesizers. $\square$ EContact! 17 (4). https://econtact.ca/17_4/scott_misunderstanding.html.

Sen, Sourya. . 2019. Developing a Hybrid Video Synthesiser for Audiovisual Performance and Composition. WMA thesis, Aalto University, Finland.

188 Shindell, Matthew. . 2019. Outlining the Black Box: An Introduction to Four Papers. $\square$ Science, Technology, \& Human Values 45 (4): 5675074.

Simondon, Gilbert. . 2017. On the Mode of Existence of Technical Objects. Translated by CCle. Malaspina and John. Rogove . Minneapolis, MN: Univocal Publishing.

Thळerge, Paul. . 1997. Any Sound You Can Imagine: Making Music/Consuming Technology. Middletown, CT: Wesleyan University Press.

Vail, Mark. . 2014. The Synthesizer: A Comprehensive Guide to Understanding, Programming, Playing, and Recording the Ultimate Electronic Music Instrument. New York: Oxford University 
Press.

Viimkl, Vesa. , and Antti. Huovilainen . 2006. Oscillator and Filter Algorithms for Virtual Analog Synthesis. Computer Music Journal 30 (2): 1931.

Virilio, Paul. . 1991. The Lost Dimension. Translated by Daniel. Moshenberg . New York: Semiotext(e).

Webb, Peter. . 2007. Exploring the Networked Worlds of Popular Music: Milieu Cultures. New York: Routledge.

\section{Human sounds and the obscenity of information}

Abbate, Carolyn. . 2016. Sound Object Lessons. Dournal of the American Musicological Society 69: 793829.

Ablinger, Peter. . n.d. Quadraturen.Thttp://ablinger.mur.at/docu11.html\#principles.

Bains, Paul. . 2006. The Primacy of Semiosis: An Ontology of Relations. Toronto, ON:

University of Toronto Press.

Barton, Ruth. . 2003. Men of Science Language, Identity and Professionalization in the Mid-

Victorian Scientific Community. WHistory of Science 41: 73س19.

Baudrillard, Jean. . (1976) 1993. Symbolic Exchange and Death. Rev. ed., translated by Ian

Hamilton. Grant . London: SAGE.

211 Baudrillard, Jean. . 1988. The Ecstasy of Communication. Translated by Bernard and

Caroline. Schutze. New York: Sylvee Lotringer.

Baudrillard, Jean. . 1993. The Transparency of Evil: Essays on Extreme Phenomena.

Translated by James. Benedict . London: Verso.

Baudrillard, Jean. . 2010. Simulacra and Simulation. Translated by Sheila Faria. Glaser . Ann

Arbor, MI: University of Michigan Press.

Bennett, Jane. . 2010. Vibrant Matter: A Political Ecology of Things. Durham, NC: Duke University Press.

Bergson, Henri. . 2005. Creative Evolution. Translated by Arthur. Mitchell . New York: Barnes \& Noble.

Brownlee, John. . 2012. Why Retina IsnEEnough. CultOfMac, June 15, 2012.

https://www.cultofmac.com/173702/why-retina-isnt-enough-feature/.

Chion, Michel. . 1994. Audio-Vision. Translated by Claudia Gorbman. New York: Columbia University Press.

Connor, Steven. . 2000. Dumbstruck: A Cultural History of Ventriloquism. Oxford: Oxford University Press.

DambCk, Christian. , and Hans-Ulrich. Lessing , eds. 2016. Dilthey als Wissenschaftsphilosoph.

Freiburg: Karl Alber.

Darley, Andrew. . 2000. Visual Digital Culture: Surface Play and Spectacle in New Media

Genres. London: Routledge.

Darwin, Erasmus. . (1794) 1809. Zoonomia. Boston, MA: Thomas and Andrews.

de Baer, Karl Ernst. . 1862. Welche Auffassung der lebenden Natur ist die richtige? Berlin:

August Hirschwald.

Deely, John. . 1994. New Beginnings: Early Modern Philosophy and Postmodern Thought.

Toronto, ON: University of Toronto Press.

Der Deriam , James. . 2001. Virtuous War. Boulder, CO: Westview.

Dilthey, Wilhelm. . (1910) 1985. Boetry and Lived Experience. Ih Poetry and Experience, edited

by Rudolf A. Makkreel and Frithjof. Rodi , 250253. Princeton, NJ: Princeton University Press.

Funkenstein, Amos. . 1986. Theology and the Scientific Imagination from the Middle Ages to the

Seventeenth Century. 2nd ed. Princeton, NJ: Princeton University Press.

Grimshaw, Mark. . 2008. The Acoustic Ecology of the First-Person Shooter: The Player

Experience of Sound in the First-Person Shooter Computer Game. SaarbrEken: Mueller.

Hauptmann, Moritz. . 1863. Klang. In JahrbCher fØmusikalische Wissenschaft, edited by

Friedrich. Chrysander . Leipzig: Breitkopf \& Httel.

Hayles, Katherine N. 2012. How We Think: Digital Media and Contemporary Technogenesis.

Chicago, IL: University of Chicago Press.

Hilbert, Martin. , and Priscila. Lpez . 2011. The Worlds Technological Capacity to Store,

Communicate, and Compute Information. \$science 332: 6065.

Hooke, Robert. . 1665. Micrographia. London: printed for John Martin.

Jrgensen, Kristine. . 2006. On the Functional Aspects of Computer Game Audio.Proceedings of Audio Mostly Conference, October 11IR, 2006, Pite,_Sweden. http://hdl.handle.net/1956/6734. 
Kapp, Ernst. . 1877. Grundlinien einer Philosophie der Technik [Elements of a philosophy of technology]. Brunswick: Westermann.

Locke, John. . (1689) 2008. An Essay Concerning Human Understanding. Abridged by Pauline Phemister. Oxford: Oxford University Press.

Marks, Lisa. . 2000. The Skin of the Film. Durham NC and London: Duke University Press.

212 Negroponte, Nicholas. . 1995. Being Digital. New York: Knopf.

Perry, Nick. . 1993. Hyperreality and Global Culture. London: Routledge.

Pollmann, Inga. . 2013. [nvisible Worlds, Visible: Uexk国Umwelt, Film, and Film Theory.Critical Inquiry 39: 777816.

Roads, Curtis. . 2004. Microsound. Cambridge, MA: MIT Press.

Rousseau, Jean-Jacques. . (1781) 1986. On the Origin of Languages. Translated by John $\mathrm{H}$. Moran and Alexander. Gode . Chicago, IL: University of Chicago Press.

Serres, Michel. . (1985) 2008. The Five Senses: A Philosophy of Mingled Bodies. Translated by Margaret. Sankey and Peter. Cowley . London: Continuum, 2008.

Siegert, Bernhard. . 2003. Passage des Digitalen. Berlin: Brinkmann \& Bose.

Strachan, Robert. . 2017. Sonic Technologies: Popular Music, Digital Culture and the Creative

Process. New York: Bloomsbury.

ThĐerge, Paul. , Kyle. Devine, and Tom. Everrett , eds. 2015. Living Stereo: Histories and

Cultures of Multchannel Sound. New York: Bloomsbury.

Trippett, David. . 2018. Music and the Transhuman Ear: Ultrasonics, Material Bodies and the Limits of Sensation. Musical Quarterly 100: 199261.

van den Oord, Aॄळn. , and Sander. Dieleman , Heiga. Zen, Karen. Simonyan, Oriol. Viuyals , Alex. Graves, Nal. Kalchbrenner, Andrew. Senior, and Koray. Kavukcuoglu . 2016. NaveNet: A Generative Model for Raw Audio.\$September 19, 2016. http://deepmind.com/blog/wavenetgenerative-model-raw-audio/.

Varro, Marcus Terentius. . 2006. Varro on the Latin Language [De lingua Latina]. Translated by Roland. Kent . Loeb Classical Library . Cambridge, MA: Harvard University Press.

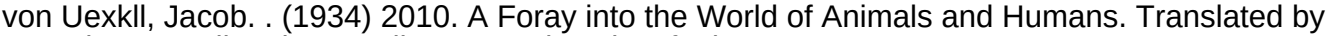
Joseph D. ODeil . Minneapolis, MN: University of Minnesota Press.

Wells, H.G. (1901) 1926. The New Accelerator.[Amazing Stories 1 (April): 5761, 96.

\section{STS confronts the Vocaloid}

Back, Les. , and Nirmal. Puwar . 2012. A Manifesto for Live Methods: Provocations and Capacities.The Sociological Review 60 (1): $6 \square 7$.

Beer, David. . 2016. The Social Power of Algorithms. Thformation, Communication and Society 20 (1): $1 \mathbb{Z}$.

Bell, David. . 2006. Science, Technology and Culture. Maidenhead: Open University Press.

Bell, Sarah A. 2016. The dB in the .db: Vocaloid Software as Posthuman Instrument. Popular

Music and Society 39 (2): 22240.

Bokaro Seikatsu Purojekuto . 2013. Bokaro P Seikatsu. Kenkyujo: Php.

Born, Georgina. . 2011. Music and the Materialization of Identities. Dournal of Material Culture 16 (4): 376388.

DeLanda, Manuel. . 2002. Intensive Science and Virtual Philosophy. New York: Continuum.

DeLanda, Manuel. . 2016. Assemblage Theory. Edinburgh: Edinburgh University Press.

Deleuze, Gilles. , and Fix. Guattari . 1987. A Thousand Plateaus: Capitalism and

Schizophrenia. London: Continuum.

DeNora, Tia. . 2000. Music and Everyday Life, Cambridge: Cambridge University Press.

Fuller, Matthew. . 2008. Software Studies: A Lexicon, Cambridge, MA: MIT Press.

Haraway, Donna J. 1991. Simians, Cyborgs, and Women: The Reinvention of Nature. London:

Free Association Books.

Hayles, N. Katherine. . 1999. How We Became Posthuman: Virtual Bodies in Cybernetics, Literature, and Informatics. Chicago, IL: University of Chicago Press.

Hennion, Antoine. . 2007. Those Things that Hold Us Together: Taste and Sociology. Cultural Sociology 1 (1): $97 \mathbb{1} 4$.

Hesmondhalgh, David. . 2013. Why Music Matters. Oxford: Wiley Blackwell.

Lash, Scott. , and Celia. Lury . 2007. Global Culture Industry: The Mediation of Things.

Cambridge: Polity.

Latour, Bruno. . 1986. The Powers of Association. Wh Power, Action and Belief: A New Sociology of Knowledge?, edited by John. Law , 264280. London: Routledge. 
Latour, Bruno. . 2002. Morality and Technology: The Ends of the Means. Theory, Culture and Society 19 (56): 247260.

Latour, Bruno. . 2005. Reassembling the Social: An Introduction to Actor-Network Theory.

Oxford: Oxford University Press.

Law, John. . 2002. Objects and Spaces.Theory, Culture and Society 19 (56): $91 \mathbb{1 0 0 5 .}$

Mackenzie, Adrian. . 2006. Cutting Code: Software and Sociality. New York: Peter Lang.

Marcus, George E. , and Erkan. Saka . 2006. Assemblage.Theory, Culture and Society, 23 (23): $101 \mathbb{1 0} 6$.

Mol, Annemarie. . 2002. The Body Multiple: Ontology in Medical Practice. Durham, NC: Duke University Press.

226 Phillips, John. . 2006. Agencement/Assemblage.Theory, Culture and Society 23 (2B): 108 미․

Plourde, Lorraine. . 2014. Distraction, Noise, and Ambient Sounds in Tokyo. Ih Sound, Space and Sociality in Modern Japan, edited by Joseph D. Hankins and Carolyn S. Stevens , 7188.

Abingdon: Routledge.

Ruppert, Evelyn., John. Law , and Mike. Savage . 2013. Beassembling Social Science Methods: The Challenge of Digital Devices.Theory, Culture and Society, 30 (4): 2246.

Savage, Mike. , and Roger. Burrows . 2007. The Coming Crisis of Empirical Sociology. $\square$ Sociology 41 (5): 885899.

Silvast, Antti. , and Mikko J. Virtanen . 2019. An Assemblage of Framings and Tamings: MultiSited Analysis of Infrastructures as a Methodology. Dournal of Cultural Economy 12 (6): 461477. ThDerge, Paul. . 2017. Musical Instruments as Assemblage. Th Musical Instruments in the 21st Century, edited by Till. Bovermann, Alberto. de Campo, Hauke. Egermann, Sarah-Indriyati. Hardjowirogo, and Stefan. Weinzierl , 59666. Singapore: Springer.

Tironi, Manuel. . 2010. Gelleable Spaces, Eventful Geographies: The Case of Santiagog Experimental Music Scene. Ih Urban Assemblages: How Actor-Network Theory Changes Urban Studies, edited by Ignacio. Farals and Thomas. Bender , 2752. Abingdon: Routledge.

Venn, Couze. . 2006. A Note on Assemblage.Theory, Culture and Society 23 (23): $107 \mathbb{L} 08$.

Virilio, Paul. . 2007. Open Sky. London: Verso.

Zoladz, Lindsay. . 2014. Batsune Miku is a Piece of Software. She May also Be the Future of Music.Vulture, November 19, 2014. https://www.vulture.com/2014/11/hatsune-miku-the-futureof-music.html.

\section{Similarity and difference in sound studies (and elsewhere)}

Condry, Ian. . 2007. Hip-Hop Japan. Durham, NC: Duke University Press.

De Kloet, Jeroen. . 2001. Red Sonic TrajectoriesBopular Music and Youth in Urban China. Enschede: Ipskamp.

DeLanda, Manuel. . 2016. Assemblage Theory. Edinburgh: Edinburgh University Press.

Dodge, Charles. , and Thomas A. Jerse . 1997. Computer Music, Synthesis, Composition and

Performance. New York: Schirmer.

Halabi, Ammar. , and Basile. Zimmermann . 2019. Waves and Forms: Constructing the Cultural in Design. IAI \& Soc 34: 4034117. doi: 10.1007/s00146-017-0713-8.

Hennion, Antoine. . 1981. Les Professionnels Du Disque. Paris: A.-M. Metailie.

Hennion, Antoine. . 1983. The Production of Success: An Anti-Musicology of the Pop Song. $\square$ Popular Music 3: 159 प193.

Hennion, Antoine. . 2003. Music and Mediation: Towards a New Sociology of Music. Th The Cultural Study of Music: A Critical Introduction, edited by Martin. Clayton, Trevor. Herbert , and Richard. Middleton, 80911. London: Routledge.

Hennion, Antoine. . 2007. Those Things that Hold Us Together: Taste and Sociology. Cultural Sociology 1 (1): 97 m14.

Hennion, Antoine. , and Cecile. Madel . 1986. Programming Music: Radio as Mediator. MMedia, Culture \& Society 8 (3): $281 B 03$.

Latour, Bruno. , and Steve. Woolgar . 1979. Laboratory Life: The Social Construction of Scientific Facts. London: SAGE.

Nader, Laura. . 1972. Ip the Anthropologist: Perspectives Gained from Studying Up.【h Reinventing Anthropology, edited by Dell. Hymes , 284311. New York: Random House. Pierce, John. . 1999. Sound Waves and Sine Waves. Wh Music, Cognition, and Computerized Sound, edited by Perry. Cook , 3756. Cambridge, MA: MIT Press. 
Pinch, Trevor J. 2000. Why You Go to a Music Store to Buy a Synthesizer: Path Dependence and the Social Construction of Technology. In Path Dependence and Creation, edited by Raghu. Garud and Peter. Karnoe, 381399. Mahwah, NJ: Lawrence Erlbaum.

Pinch, Trevor J. , and Karin. Bijsterveld . 2004. Sound Studies: New Technologies and Music. $\square$ Social Studies of Science 34 (5): 635648.

Pinch, Trevor J. , and Karin. Bijsterveld . 2012. The Oxford Handbook of Sound Studies. New York: Oxford University Press.

Pinch, Trevor J. , and Frank. Trocco . 2002. Analog Days: The Invention and Impact of the Moog Synthesizer. Cambridge, MA: Harvard University Press.

Sterne, Jonathan. . 2007. Media or Instruments? Yes. Dffscreen 11 (89): 1 [18.

Sterne, Jonathan. . 2012. Mp3: The Meaning of a Format. Durham, NC: Duke University Press. Strawn, John. . 1996. Digital Audio Concepts. Wh The Computer Music Tutorial, edited by Curtis. Roads, 548. Cambridge, MA: MIT Press.

238 Zimmermann, Basile. . 2006. De IFinpact de la technologie occidentale sur la culture chinoise: Les pratiques des musiciens lectroniques $\mathbb{P E n}$ comme terrain dbbservation de la relation entre objets techniques et cration artistique. $\mathbb{P h D}$ diss., Universit $[$ le Genve.

Zimmermann, Basile. . 2015. Waves and Forms: Electronic Music Devices and Computer Encodings in China. Cambridge, MA: MIT Press.

\section{Smartphones, streaming platforms, and the infrastructuring of digital music practices}

Aguiar, Luis. , and Joel. Waldfogel . 2018. Platforms, Promotion, and Product Discovery:

Evidence from Spotify Playlists. Working paper No. 24713. Cambridge, MA: National Bureau of Economic Research.

Akrich, Madeleine. . 1992. The De-Scription of Technical Objects. पh Shaping

Technology/Building Society: Studies in Sociotechnical Change, edited by Wiebe J. Bijker and John. Law , 205R24. Cambridge, MA: MIT Press.

Bartmanski, Dominik. , and Ian. Woodward . 2015. Vinyl: The Analogue Record in the Digital Age. London: Bloomsbury.

Bijker, Wiebe E. , Thomas Parke. Hughes, and Trevor J. Pinch, eds. 1987. The Social Construction of Technological Systems: New Directions in the Sociology and History of Technology. Cambridge, MA: MIT Press.

Bonini, Tiziano. , and Alessandro. Gandini . 2019. Eirst Week Is Editorial, Second Week Is Algorithmical Platform Gatekeepers and the Platformization of Music Curation. Social Media + Society 5 (4): $1 \mathbb{1 T l}$.

Bowker, Geoffrey C. , and Susan Leigh. Star . 1999. Sorting Things Out: Classification and Its Consequences. Cambridge, MA: MIT Press.

Bull, Michael. . 2000. Sounding Out the City: Personal Stereos and the Management of Everyday Life. Oxford: Berg.

Bull, Michael. . 2007. Sound Moves: iPod Culture and Urban Experience. London: Routledge.

Couldry, Nick. , and Andreas. Hepp . 2018. The Mediated Construction of Reality. London: John Wiley \& Sons.

Dant, Tim. . 2008. BPod... Icon.\$Studi Culturali 5 (3): 3553174.

DeNora, Tia. . 2000. Music in Everyday Life. Cambridge: Cambridge University Press.

254 Edwards, Paul N. 2003. mfrastructure and Modernity: Force, Time, and Social Organization in the History of Sociotechnical Systems. In Modernity and Technology, edited by Thomas J.

Misa, Philip. Brey, and Andrew. Feenberg , 185R26. Cambridge, MA: MIT Press.

Eriksson, Maria. , Rasmus. Fleischer, Anna. Johansson, Pelle. Snickars, and Patrick.

Vonderau . 2019. Spotify Teardown: Inside the Black Box of Streaming Music. Cambridge, MA: MIT Press.

Gillespie, Tarleton. . 2010. The Politics of Platforms. $\mathbb{N}$. Tew Media \& Society 12 (3): 347364.

Gillespie, Tarleton. . 2018. Custodians of the Internet: Platforms, Content Moderation, and the Hidden Decisions that Shape Social Media. New Haven, CT: Yale University Press.

Hagen, Anja N. , and Marika. Lders . 2017. Slocial Streaming? Navigating Music as Personal and Social.Convergence 23 (6): 64359.

Hayes, Adam. . 2019. The Socio-Technological Lives of Bitcoin. Theory, Culture \& Society, 36 (4): 4972.

Hartmann, Maren. . 2017. Dircuit(s) of Affective Infrastructuring: Smartphones and Electricity. ஐh Smartphone Cultures, edited by Jane. Vincent and Leslie. Haddon, 11区4. London: Routledge. 
Helmond, Anne. . 2015. The Platformization of the Web: Making Web Data Platform Ready. $\square$ Social Media + Society 1 (2): 260275 .

Helmond, Anne. , David B. Nieborg , and Fernando N. van der Vlist . 2019. Elacebooks Evolution: Development of a Platform-as-Infrastructure. ஐnternet Histories 3 (2): $123 \llbracket 46$. Hughes, Thomas Parke. . 1983. Networks of Power: Electrification in Western Society, 1880प1930. Baltimore, MD: Johns Hopkins University Press.

Kitchin, Rob. . 2017. Thinking Critically about and Researching Algorithms. Пhformation, Communication \& Society 20 (1): 1420.

Magaudda, Paolo. . 2011. When Materiality Bites BackDigital Music Consumption Practices in the Age of Dematerialization. Dournal of Consumer Culture 11 (1): 1536.

Magaudda, Paolo. . 2018. The Future of Digital Music Infrastructures: Expectations and Promises of the Blockchain Bevolution. In Popular Music in the Post-Digital Age: Politics, Economy, Culture and Technology, edited by Eva. Les Mazierska Gillon , and Tony . Rigg , 5168. London: Bloomsbury.

Magaudda, Paolo. , and Tiziana. Piccioni . 2019. Practice Theory and Media Infrastructures: mfrastructural Disclosures In Smartphone Use. \$ociologica: International Journal for Sociological Debate 13 (3): 4558.

Marshall, Lee. . 2015. etSKeep Music Special. FSpotify[On-Demand Streaming and the Controversy over Artist Royalties. Creative Industries Journal, 8 (2): $177 \square 89$.

Montfort, Nick. , and lan. Bogost . 2009. Racing the Beam: The Atari Video Computer System. Cambridge, MA: MIT Press.

Morris, Jeremy W. 2015a. Selling Digital Music, Formatting Culture. Oakland, CA: University of California Press.

Morris, Jeremy W. . 2015b. Quration by Code: Infomediaries and the Data Mining of Taste. $\square$ European Journal of Cultural Studies, 18 (45): 446463.

Nag, Wenche. . 2018. Music Streams, Smartphones, and the Self. Mobile Media \& Communication, 6 (1): 1936.

Nieborg, David B. , and Thomas. Poell . 2018. The Platformization of Cultural Production: Theorizing the Contingent Cultural Commodity. WNew Media \& Society, 20 (11): 42754292. 255 Oudshoorn, Nelly. , and Trevor J. Pinch, eds. 2003. How Users Matter: The CoConstruction of Users and Technologies. Cambridge, MA: MIT Press.

Parks, Lisa. , and Nicole. Starosielski , eds. 2015. Signal Traffic: Critical Studies of Media Infrastructures. Urbana, IL: University of Illinois Press.

Peters, John Durham. . 2015. The Marvelous Clouds: Toward a Philosophy of Elemental Media. Chicago, IL: University of Chicago Press.

Plantin, Jean-Christophe. , Carl . Lagoze, Paul N. Edwards, and Christian. Sandvig . 2016.

mfrastructure Studies Meet Platform Studies in the Age of Google and Facebook. WNew Media \& Society 20 (1): 2933110.

Plantin, Jean-Christophe. , and Aswin. Punathambekar . 2019. Digital Media Infrastructures: Pipes, Platforms, and Politics. Media, Culture \& Society 41 (2): 163ญ74.

Prey, Robert. . 2016. Musica Analytica: The Datafication of Listening. In Networked Music Cultures: Contemporary Approaches, Emerging Issues, edited by RaphaDNowak and Andrew. Whelan , 3148. London: Palgrave Macmillan.

Star, Susan Leigh. , and Geoffrey C. Bowker . 2006. Bow to Infrastructure. Wh Handbook of New Media: Social Shaping and Social Consequences of ICTs, edited by Leah A. Lievrouw and Sonia M. Livingstone, 230245. London: SAGE.

Star, Susan Leigh. , and Karen. Ruhleder . 1996. Steps toward an Ecology of Infrastructure: Design and Access for Large Information Spaces. Whformation Systems Research 7 (1): $111 \mathbb{1 1 3 4 .}$ Sterne, Jonathan. . 2012a. MP3: The Meaning of a Format. Durham, NC: Duke University Press.

van Dijck, Jos $\square$ Thomas. Poell , and Martijn. de Waal . 2018. The Platform Society: Public Values in a Connective World. Cambridge: Oxford University Press.

Woolgar, Steve. . 1990. Donfiguring the User: The Case of Usability Trials. The Sociological Review 38 (1): 5899. 


\section{Tracing the music actor-network}

Akrich, Madeleine. . 1992. The De-Scription of Technical Objects. Шh Shaping

Technology/Building Society: Studies in Sociotechnical Change, edited by Wiebe E. Bijker and John. Law, 205R24. Cambridge, MA: MIT Press.

Callon, Michel. . 2001. Actor-Network Theory. In International Encyclopedia of the Social and Behavioral Sciences, edited by Neil J. Smelser and Paul B. Baltes, 6266. Oxford: Pergamon. Callon, Michel. , and Bruno. Latour . 1981. Unscrewing the Big Leviathan: How Actors Macrostructure Reality and How Sociologists Help Them to Do So.Шn Advances in Social Theory and Methodology: Toward an Integration of Micro- and Macro-Sociologies, edited by Karin D. Knorr Cetina and Aaaron V. Cicourel , 277BD3. Boston, MA: Routledge and Kegan Paul.

Crawford, Matthew B. 2015. The World beyond Your Head: On Becoming an Individual in an Age of Distraction. New York: Farrar, Straus and Giroux.

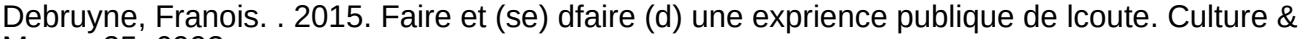
Muses 25: 6993.

Debruyne, Franסis. . 2016. Environnements numbiques de ICbute et culture publique: Vers de nouvelles formes de domestication de lexprience musicale. In O $\mathrm{V}$ a la musique?, edited by Philippe. Le Guern , 810R. Paris: Presses des Mines, Libres opinions.

Dewey, John. . 1905. Beality as Experience.Dournal of Philosophy, Psychology and Scientific Methods 3 (10): 253257.

Dewey, John. . 1934. Art as Experience. New York: Minton, Balch.

Dewey, John. . 1977. The Middle Works (1899924). Vol. 4. Carbondale, IL: Southern Illinois University Press.

Eriksson, Maria. , Rasmus. Fleischer, Anna. Johansson, Pelle. Snickars, and Patrick. Vondereau . 2018. Spotify Teardown: Inside the Black Box of Streaming Music. Cambridge, MA: MIT Press.

Garfinkel, Harold. . 1967. Studies in Ethnomethodology. Englewood Cliffs, NJ: Prentice Hall. Gibson, James Jerome. . 1979. The Ecological Approach to Visual Perception. Boston, MA: Houghton Mifflin.

Goody, Jack. . 1977. The Domestication of the Savage Mind. Cambridge: Cambridge University Press.

Goody, Jack. . 1986. The Logic of Writing and Organization of Society. Cambridge: Cambridge University Press.

Hennion, Antoine. . 1993. La passion musicale: Une sociologie de la mđlation. Paris: Mtäilii Hennion, Antoine. . 2009. Bflexivits Lactivit@le lamateur.RBSeaux 135: 5378.

Hennion, Antoine. , Sophie. Maisonneuve, and Emilie. Gomart . 2000. Figures de lamateur: Formes, objets, pratiques de lamour de la musique aujourdbui. Paris: La Documentation franalse.

Hennion, Antoine. , Sophie. Maisonneuve, and Emilie. Gomart . 2013. DUne sociologie de la mđliation 匹une pragmatique des attachements, \$Sociologies [Online], Thסries et recherches.

Hennion, Antoine. , Sophie. Maisonneuve, and Emilie. Gomart . 2016. Erom ANT to Pragmatism: A Journey with Bruno Latour at the CSI. New Literary History 47: 289308.

Hennion, Antoine. , Sophie. Maisonneuve, and Emilie. Gomart . 2017. Attachments, You Say? How a Concept Collectively Emerges in One Research Group. Dournal of Cultural Economy 10: $112 \mathbb{1 I D} 1$.

267 Latour, Bruno. . 1988. The Prince for Machines as Well as for Machinations. In Technology and Social Change, edited by Brian. Elliott , 3562. Edinburgh: Edinburgh University Press.

Latour, Bruno. . 2005. Reassembling the Social: An Introduction to Actor-Network Theory. Oxford: Oxford University Press.

Latour, Bruno. . 2012. Enqute sur les modes dexistence: Une anthropologie des Modernes.

Paris: La dCbuverte.

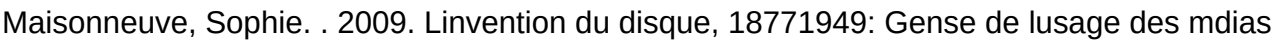
musicaux contemporains. Paris: ditions des Archives Contemporaines.

Star, Susan Leigh. . 1999. The Ethnography of Infrastructure. [American Behavioral Scientist 43 (3): 377391.

Star, Susan Leigh. , and Karen. Ruhleder . 1996. Steps toward an Ecology of Infrastructure:

Design and Access for Large Information Spaces. Information Systems Research 7 (1): $111 \llbracket 34$. 


\section{Musicalized images}

Agamben, Giorgio. . 2009. What Is an Apparatus? Translated by David. Kishik and Stefan. Pedatella . Stanford, CA: Stanford University Press.

Akrich, Madeleine. . 1993. Ces objets techniques et leurs utilisateurs, de la conception 荡ction. $\square$ In edited by Bernard. Coenein , Nicolas. Dodier , and Laurent. ThVenot . Les objets dans laction: De la maison au laboratoire, 3557. Raisons Pratiques 4. Paris: đitions de IEHESS. Barboza, Pierre. , and Jean-Louis. Weissberg , eds. 2007. LשThage acter Scharisations numfiques. Paris: LBarmattan.

Barthes, Roland. . 1984. En sortant du cinma. In edited by Roland Barthes. Le bruissement de la langue: Essais critiques IV, 407412. Paris: Le Seuil.

Becker, Howard S. 1982. Art Worlds. Berkeley, CA: University of California Press.

Bessy, Christian. , and Francis. Chateauraynaud . 1995. Experts et faussaires: Pour une sociologie de la perception. Paris: Mtaili $\square$

Boissier, Jean-Louis. . 2004. La relation comme forme: LEteractiviten art. Geneva: Mamco. Boltanski, Luc. , and Laurent. ThZenot . 1991. De la justification: Les Conomies de la grandeur. Paris: Gallimard.

Bourdieu, Pierre. . 1992. Les rgles de lart: Gense et structure du champ litt君. Paris: Le Seuil. Cardon, Dominique. . 2010. La dmocratie Internet. La Rpublique des Ides. Paris: Le Seuil. Compagnon, Antoine. . 1998. Le Dmon de la thørie. Paris: Le Seuil.

Conein, Bernard. , Nicolas. Dodier, and Laurent. Thøenot . 1993. Les objets dans laction: De la maison au laboratoire. Raisons Pratiques 4. Paris: đitions de IEHESS.

De Certeau, Michel. . 1990. LEvention du quotidien: Arts de faire. Paris: Gallimard.

Dewey, John. . 1934. Art as Experience. New York: Minton, Balch.

Dewey, John. . 1954. The Public and Its Problems. Athens, OH: Ohio University Press.

Duguet, Anne-Marie. . 2002. DJuer I[Tage. Dmes: Jacqueline Chambon.

Eco, Umberto. . 1989. The Open Work. Translated by Anna. Concogni . Cambridge, MA: Harvard University Press.

Flichy, Patrice. . 2010. Le sacre de lamateur. Paris: Le Seuil.

282 Foucault, Michel. . 1975. Surveiller et punir: Naissance de la prison. Paris: Gallimard.

Fourmentraux, Jean-Paul. . 2004. Qute du public et tactiques de fidlisation: Une sociologie du travail et de lusage artistique des NTIC. RSeaux 125: 81M1.

Fourmentraux, Jean-Paul. . 2007. Dpreuve des Interfaces: Sociologie des arts mđlias. Пh Interfaces numfilques, edited by Imad. Saleh and Djeff. Regottaz . Paris: Herms Sciences. Fourmentraux, Jean-Paul. . 2008. Duvre en devenir: Sociologie de la communication et des

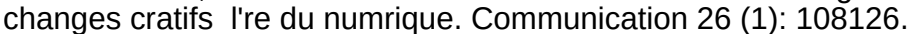

Fourmentraux, Jean-Paul. . 2010. Art et Internet: Les nouvelles figures de la cration. Rev. ed. Paris: CNRS ditions.

Fourmentraux, Jean-Paul. . 2017. Images Interactives. Brussels: La Lettre vole

Genette, Gaard. . 1982. Palimpsestes. Paris: Le Seuil.

Genette, GLard. . 1996. LUVre de lart. Paris: Le Seuil.

Goodman, Nelson. . 1976. Languages of Art: An Approach to a Theory of Symbols.

Indianapolis, IN: Hackett.

Goodman, Nelson. . 1984. Of Mind and Other Matters. Chapters 4 (Art in Theory) Zand 5 (Art in Action[ Cambridge, MA: Harvard University Press.

Heinich, Nathalie. . 1998. Le triple jeu de lart contemporain. Paris: Les ditions de Minuit.

Hennion, Antoine. . 1997. La musicalisation des arts plastiques. Пh Images numilques: L'aventure du regard, edited by Odile. Blin and Jacques. Sauvageot. Rennes: Presses Universitaires de Rennes: $147 \mathbb{1 1 5 1 .}$

Hennion, Antoine. . 2007. La passion musicale: une sociologie de la mđlation. Paris: Mtäili $\square$ Jacquinot-Delaunay, Geneviฉe. , and Laurence. Monnoyer , eds. 1999. e dispositif: Entre usage et concept. Herms La revue 25.

Laplantine, Franois. , and Alexis. Nouss . 2001. Mtissages, de Arcimboldo ZZombi. Paris: ditions Pauvert.

Latour, Bruno. . 2005. Changer de socittiRefaire de la sociologie. Paris: La DCbuverte. Latour, Bruno. , and Michel. Callon . 1991. La science telle qu'elle se fait. Paris: La DCbuverte. Maigret, Eric. , and Eric. Mac $\square$ 2005. Penser les mđlacultures. Paris: Armand Colin. 
McLuhan, Marshall. . (1964) 2015. Understanding Media: The Extensions of Man. Berkeley, CA: Gingko Press.

Menger, Pierre-Michel. . 1993. Le paradoxe du musicien. Paris: Flammarion.

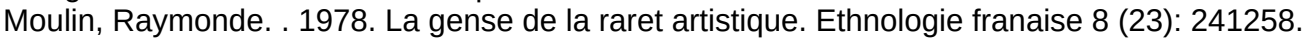

Moulin, Raymonde. . 1992. Lartiste, l'institution et le march $\square$ Paris: Flammarion.

Sangsue, Daniel. . 1994. La Parodie. Paris: Hachette.

Shusterman, Richard. . 2000. Pragmatist Aesthetics: Living Beauty, Rethinking Art. 2nd ed. Lanham, MD: Rowman and Littlefield.

Souriau, tienne . 1956. [uvre faire.Bulletin de la Socifffranalse de philosophie, February 25, 1956.

Shusterman, Richard. . 2009. Les diffeents modes dexistence. Followed by LUvre faire. Paris: Presses universitaires de France.

Thøenot, Laurent. . 1984. Bules and Implements: Investment in Forms. Translated by Jill. Forbes . Social Science Information 23 (1): 145.

Vinck, Dominique. . 1999. [es objets intermđllaires dans les rßeaux de coopŁation scientifique. Revue Franalse de Sociologie 40 (2): 385414.

Weissberg, Jean-Louis. . 2000. Dauteur en collectif: Entre l'individu et l'indivis. Пles Cahiers du numilque 1 (4): $113 \mathbb{1 2 4}$. 